University of Rhode Island

DigitalCommons@URI

Open Access Dissertations

1972

\title{
GLYOXAL AND ESTRADIOL MEDIATED ALTERATIONS IN RAT UTERINE HISTONE ACETYLATION
}

Robert Louis Procaccini

University of Rhode Island

Follow this and additional works at: https://digitalcommons.uri.edu/oa_diss

\section{Recommended Citation}

Procaccini, Robert Louis, "GLYOXAL AND ESTRADIOL MEDIATED ALTERATIONS IN RAT UTERINE HISTONE ACETYLATION" (1972). Open Access Dissertations. Paper 162.

https://digitalcommons.uri.edu/oa_diss/162

This Dissertation is brought to you for free and open access by DigitalCommons@URI. It has been accepted for inclusion in Open Access Dissertations by an authorized administrator of DigitalCommons@URI. For more information, please contact digitalcommons-group@uri.edu. 
GLYOXAL AND ESTRADIOL MEDIATED ALTERATIONS

IN RAT UTERINE HISTONE ACETYLATION

BY

ROBERT LOUIS PROCACCINI

A THESIS SUBMITTED IN PARTIAL FULFILLMENT OF THE REQUIREMENTS FOR THE DEGREE OF DOCTOR OF PHILOSOPHY

IN

PHARMACEUTICAL SCIENCES

UNIVERSITY OF RHODE ISLAND

1972 


\section{DOCTOR OF PHILOSOPHY THESIS}

OF

ROBERT LOUIS PROCACCINI

\section{Approved:}

Thesis Committee:

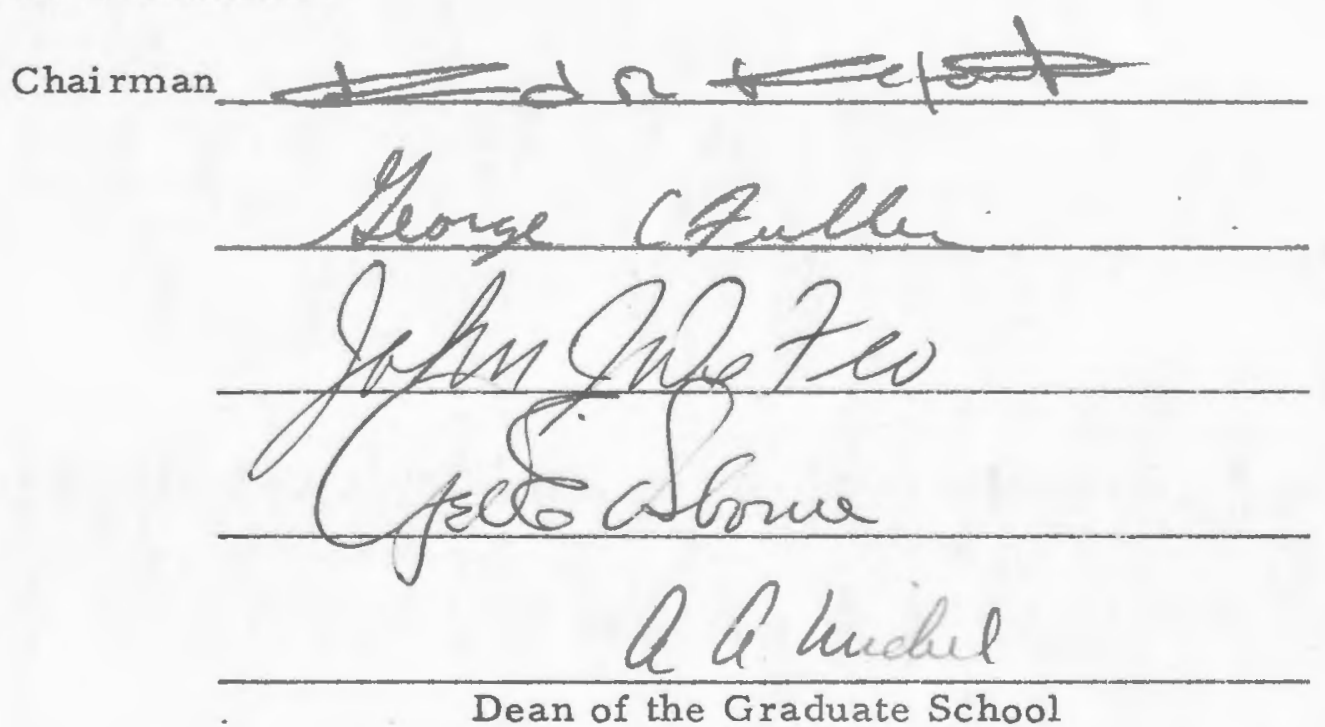

UNIVERSITY OF RHODF ISIAND 


\section{ABSTRACT}

Procaccini, Robert Louis. Ph. D. University of Rhode Island, June, 1972. Glyoxal and Estradiol Mediated Alterations in Rat Uterine Histone Acetylation. Major Professor: Dr. David R. DeFanti.

The immature rat uterus was developed as a model in which to measure alterations in histone acetylation in a target organ following hormonal stimulation. The effect of various glyoxal derivatives on histone acetylation and several other parameters was measured in the ute rine tissue of untreated and estradiol treated animals. Six day treatment with glyoxal monohydrate and methylglyoxal-bis-guanylhydrazone (Methy1-GAG) decreased uterine wet weight and partially blocked estradiol mediated alterations in uterine wet weight in animals receiving concomitant estradiol and glyoxal treatment.

The dose dependent in vitro inhibition of uterine histone acetylation is thought to occur through direct action on the acetylation system. The $I_{50}$ values reported for methylglyoxal and phenylglyoxal suggest that the drugs are equally effective as inhibitors of uterine histone acetylation. Estradiol mediated alterations in uterine histone acetylation were characterized as a rapid depression of enzyme activity; 24 hours following hormone treatment this enzyme activity was elevated above control levels. The elevation in histone acetylation following estradiol treatment was blocked by either methylglyoxal or phenylglyoxal administered 20 hours after estradiol. Uterine wet weight, total DNA, 
RNA/DNA and protein/DNA ratios were not affected by this treatment. These data suggest that histone acetylation may not be of primary importance in estradiol stimulation of the rat uterus.

The phenylglyoxal mediated depression of uterine histone acetylation preceded the alterations in RNA/DNA and protein/DNA ratios observed when phenylglyoxal pretreatment was extended to 48 hours. Elevations in total DNA and protein/DNA ratios in the uterus of estradiol treated rats were partially suppressed in animals pretreated with phenylglyoxal, whereas the RNA/DNA ratio was not affected in the se animals.

Results from this study suggest that the glyoxal mediated blockade of uterine histone acetylation may lead to an alteration in nucleic acid content of the hormonally stimulated uterus. 


\section{ACKNOWLEDGEMENTS}

I would like to express my deep appreciation to Dr. David R. DeFanti, Dr. John J. DeFeo and Dr. George Osborne for their continued help and encouragement throughout my graduate education.

I would like to thank my fellow graduate students for their helpful comments, criticisms and suggestions expressed throughout this study. 


\section{DEDICATION}

To my wife, Ruth Ann, and to my parents, for their endless patience and encouragement. 
TABLE OF CONTENTS

Page

ABSTRACT $\ldots \ldots \ldots \ldots \ldots \ldots$

ACKNOWLEDGEMENTS .................... ii

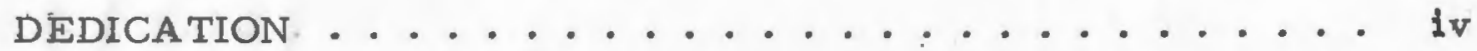

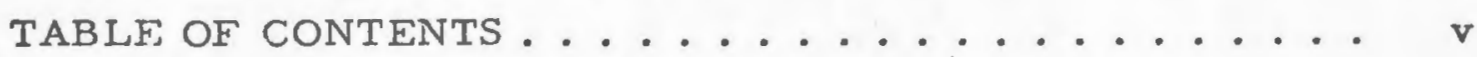

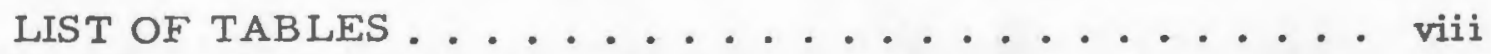

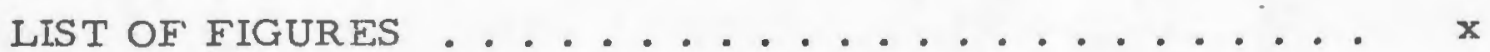

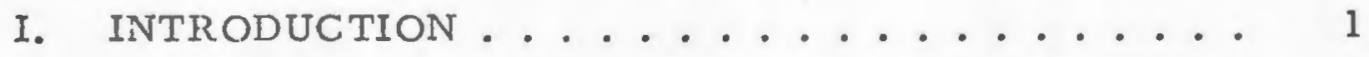

II. LITERATURE SURVEY .................. 3

A. Structure and Function of Histones ...... 4

B. Histones and Nuclear Mechanisms ..... 8

C. Glyoxals and Their Cellular Mechanisms ... 12

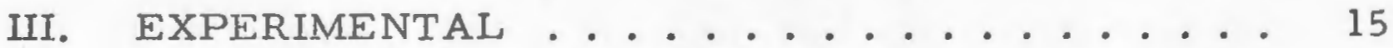

A. Animals ................... 15

B. Subcellular Fractionization and Localization of

Histone Acetylating Activity........ 15

C. In Vitro Studies .............. 16

1. Temperature study: Determination of temperature coefficient $\left(Q_{10}\right) \ldots \ldots 16$

2. Dose response for methyl- and phenyl-

glyoxal: Determination of $\mathrm{I}_{50} \ldots \ldots 17$ 
3. Effect of enzyme-drug and histone-drug preincubation histone acetylation ..... 17

a. Enzyme-drug ............. 17

b. Histone-drug ............. 18

D. In Vivo Studies .................. 19

1. Tissue weight: 'Alterations with Estradiol and Glyoxals ...............

2. Estradiol and Phenylglyoxal: Initial

Response............... 20

3. Activity of Estradiol and Glyoxals: Time Response.............. 21

4. Drug interaction: Estradiol and Glyoxals . . 22

E. Assay of Histone Acetylation ......... 23

F. Protein Determination .......... 24

G. Extraction of Nucleic Acids ........ 25

H. Estimation of DNA .......... 27

I. Estimation of RNA ........... 27

J. Statistical Methods ............ 28

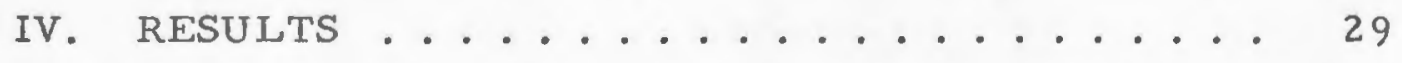

v. DISCUSSION ...................... 57

VI. SUMMARY AND CONCLUSIONS ........ 69

VII. REFERENCES .................... 72 
Page

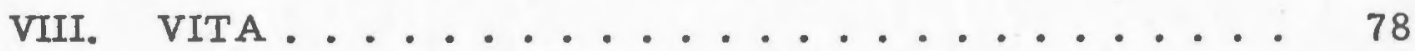

IX. APPENDIX .................... 79 


\section{LIST OF TABLES}

Table

1 Inhibition of in vitro histone acetylation by glyoxal derivatives: Index of inhibition $\left(I_{50}\right.$ value $) . . . .31$

2 In vitro inhibition of histone acetylation: Effect of phenylglyoxal-enzyme preincubation .........

3 In vitro inhibition of histone acetylation: Effect of phenylglyoxal-histone preincubation .........

4 Effect of glyoxal derivatives on body weight and uterine wet weight in immature female rats ..........

5 Effect of combined glyoxal or Methyl-GAG and estradiol administration on uterus/body ratio and liver/body ratio in immature female rats: Comparison between glyoxal or Methyl-GAG pretreated and estradiol treated animals ..............

6 Effect of methylglyoxal treatment on uterine weight and histone acetylation in untreated and estradiol pretreated rats ..................

7 Effect of phenylglyoxal treatment on uterine weight and histone acetylation in untreated and estradiol pre treated rats ..................

8 Comparison of alterations in uterine histone acetylation and uterine wet weight at two dose levels of methyl glyoxal and phenylglyoxal ..............

9 Effect of methylglyoxal and phenylglyoxal treatment on the estradiol mediated stimulation of histone acetylation and uterine wet weight ........ 50

10 Effect of 4 hour phenylglyoxal treatment on wet weight and nucleic acid content in the immature rat uterus ...

11 Effect of 48 hour phenylglyoxal pretreatment on estradiol mediated alterations in immature rat uterus. . 
Table

12 Effect of 48 hour phenylglyoxal pretreatment on estradiol mediated alterations in immature rat

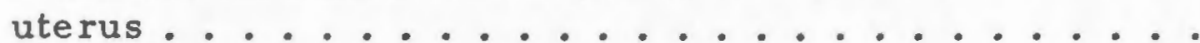

13 Effect of 48 hour pretreatment on estradiol mediated alterations in the immature rat uterus: Comparison between hormone treatment alone and in combination with phenylglyoxal ............. 56 


\section{LIST OF FIGURES}

Figure

Page

1 Effect of (a) phenylglyoxal and (b) methylglyoxal

on in vitro histone acetylation by a cell-free

rat uterine system ............. 30

2 Histone acetylation in soluble uterine fraction from

rats treated with estradiol alone and in combination

with phenylglyoxal .............. 38

3 Alteration of histone acetylation by estradiol and phenylglyoxal .............. . . 40

4 Alteration of ute rine wet weight by estradiol and phenylglyoxal ..................

5 Alteration of histone acetylation in rat uterus by estradiol and methylglyoxal, expressed as percent change from control ...............

6 Alteration of histone acetylation in rat uterus by estradiol and phenylglyoxal, expressed as percent change from control ............. 48 


\section{INTRODUCTION}

The biological activity of glyoxal de rivatives (ketoaldehydes) has been the subject of numerous literature reports. In 1967 , Szent-Gyorgyi proposed that these compounds may inhibit cell growth. Interestingly, methylglyoxal and propylglyoxal were shown to inhibit cell division in mouse lymphoma cells (Gregg, 1968). Klamerth (1968) suggested that glyoxal may elicit its cellular inhibitory properties at the DNA replication level. Scaife (1969) has presented evidence that $\beta$-ethoxy - $\alpha$-ketobutyraldehyde (Kethoxal, Upjohn Pharmaceutical) inhibits cell division and protein synthesis. Although kethoxal and anothe $r$ ketoaldehyde, methylglyoxal-bis-guanylhydrazone, have been used therapeutically for leukemia, the exact antileukemic mechanism is not known (Henderson, 1969).

Concomitantly, a growing body of observations (Allfrey et al. , 1963; Pogo et al. , 1966, 1968) indicates that histone metabolism, in particular, histone acetylation, may be involved in regulating DNA function. The inhibitory action of histones on cellular processes may itself be regulated, in part, by the acetylation reaction (Georgiev, 1969; Tsanov and Sendov, 1971). It follows that inhibition of histone acetylation may lead to alterations in overall histone function. In addition, previous workers have reported (Pogo et al., 1966) alterations in histone acetylation following hormonal stimulation. 
As a result, this investigation was designed to study the effects of glyoxal derivatives on histone acetylation in a hormonally alterable system. 


\section{LITERATURE SURVEY}

During the past two decades, numerous investigators have tried to elucidate the structure, mechanism of action, and general cellular function of histones. Because the se low molecular weight, highly alkaline proteins are closely associated with deoxy ribonucleic acid in the nuclear apparatus of cells, early investigators focused their attention on the search for proof of a regulatory function involving the histones.

The first hypothesis was presented by Stedman and Stedman (1950) that histones were inhibitors of genetic activity. Later, the suggestion was made that the evolution of the structure and function of various histone species parallels, to some degree, the evolution of the genes themselves. Georgiev (1969) stated that histones appeared in evolution at the same time the cell acquired two of its fundamental properties: a nuclear membrane and the capacity for differentiation. DeLange and Smith (1971) pointed out that evolutionary conservatism is evident in the structure of histones. Histone IV (arginine-rich), with an approximate evolutionary mutation rate of $0.06 / 100$ residues / 100 million years, is 33 times more genetically stable than any known protein. It has been proposed that the biological function of the histones demands such close control of its structure that even slight modifications in its amino acid sequence could not be tolerated (Bradbury, 1969). 


\section{STRUCTURE AND FUNCTION OF HISTONES}

Approximately 15 percent of the nuclear component of eukaryotic cells is composed of histone protein. The histones are believed to exist in five distinct fractions: $\mathrm{fl}$, lysine-rich; $\mathrm{f} 2 \mathrm{~b}$, moderately lysine-rich; and $f 2 a 1, f 2 a 2$, and $f 3$, arginine-rich histones. Each of the fractions is thought to comprise 20 percent of the whole histone (Richards and Pardon, 1970). Virtually all of the deoxyribonucleic acid (DNA) in the nucleus exists as a complex with histones. It is generally believed that histones attach to DNA through electrostatic linkages. Of these, the strongest are ionic linkages between the phosphate groups of the DNA and the basic residues lysine (Eammonium), arginine (guanidinium), and histidine (Richards and Pardon, 1970;

Lewin, 1970). Combard and Venduly (1970) presented evidence indicating that different histone fractions interact with DNA at different sites on the DNA molecule. They found lysine-rich histones in association with DNA in regions of relatively high adenine-thymine base content, whereas arginine-rich histones were found in association with guanine and cytosine-rich regions.

Not all the histone fractions affect the activity of the DNA complex to the same extent; for example, lysine-rich histone (fi) inhibits the DNA-dependent-RNA polymerase reaction to a lesser extent than does the arginine-rich histone (f3). Further, prior acetylation of uterine histone markedly depresses the inhibitory effect of 
histones on in vitro RNA synthesis (Teng and Hamilton, 1969). The inhibitory effect of arginine-rich histone fractions on DNA dependentRNA polymerase is thought to be related to the thiol/disulfide ratio of the fraction. Hilton and Stockton (1966) found that diffuse, active chromatin has a greater proportion of sulfur residues as free thiol groups than does dense, inactive chromatin. Purified $\mathrm{f} 3$ histone was annealed with DNA, and purified RNA polymerase was used to measure the efficiency of the treated DNA as a template. When histone thiol groups were oxidized to the disulfide form before the annealing step, histone-histone aggregates were produced which possessed augmented inhibitory properties against DNA template activity. These results suggested that continuous RNA synthesis in mammalian cells may be partly dependent upon the existence of cysteine-containing histones in their thiol form (Ord and Stocken, 1969).

Extensive studies of histone metabolism in mammalian cells indicate that these proteins undergo structural alterations by at least three enzymatic processes: (1) acetylation (Allfrey et al., 1964; Pogo et al. , 1966; Pogo et al., 1968), (2) methylation (Paik and Kim, 1969; Paik and Kim, 1971), and (3) phosphorylation (Langan, 1969). The enzymatic modification of histone protein may represent an early event in the complex process of gene activation for subsequent RNA and protein synthesis (Pogo et al., 1968). To support this theory, several model systems have been proposed for the study of histones 
and their enzymatic modification during periods of increased growth believed to involve enhanced genetic activity.

Incorporation studies have established that transformation (activation) of human lymphocytes by phytohemagglutinin involves an increase in RNA synthesis (Rubin and Cooper, 1963) and in protein synthesis (Bach and Hirschorn, 1963), using uridine-2- ${ }^{14} \mathrm{C}$ and alanine-1 $-{ }^{14} \mathrm{C}$, respectively. Increased histone acetylation seen in response to phytohemagglutinin preceded the increase in RNA and protein synthesis; at the same time, cells not stimulated by phytohemagglutinin did not demonstrate this increase in acetylation of their histones (Pogo et al., 1966).

Pogo et al. (1968), studying $r$ at liver regeneration, showed that turnover of ${ }^{3} \mathrm{H}$-acetyl groups incorporated into histones decreased in partially hepatectomized rats. Rates of ${ }^{3} \mathrm{H}-\mathrm{UMP}$ incorporation into RNA reached maximum levels only after histone acetylation had peaked. Pogo (1969) found that nucleolar activation in this system began at 2 hours and chromatin activation at about 6 to 8 hours after partial hepatectomy. He also found that arginine-rich (f2al) histones were highly and rapidly acetylated. When the acetylated histones were treated with $2 \mathrm{M}$ hydroxylamine for one hour, all the labeled acetate was found to be resistant to cleavage from histone. Since hydroxylamine, under the se conditions, will hydrolyze O-acetyl but not N-acetyl linkages, and since, under similar conditions, the histone fraction $f 3$ 
(arginine-rich) lost 55 percent of its acetyl content, the presence of O-acetylated groups was indicated. Verifications of the presence of radioactive acetyl groups was accomplished by acid hydrolysis and steam distillation of volatile acetic acid.

An extensive study by Paik and Kim (1971) has shown that at least three enzymes found in the cytosol fraction of calf thymus are capable of methylating histones. Protein methylase I(S-adenosyl-Lmethionine: protein-arginine methyltransferase) methylates the guanido group of a rginine residues in histones yielding a product identified as $\omega-\mathrm{N}$-methylarginine. When protein methylase I was measured in rapidly growing hepatoma, the enzyme activity was found to increase by 50 to 100 percent (Paik et al., in press). Kaye and Sheratyky (1969) obtained an enzyme preparation from the $105,000 \times \mathrm{g}$ supernatant fraction of rat organs which they found capable of transferring methyl groups from S-adenasyl-L-methionine and acetyl groups from acetyl-COA to arginyl and lysyl residues in histones. The most effective acceptors were unfractionated histones of rat organs, calf thymus arginine-rich histones and poly-L-arginine.

An enzyme system derived from rat brain nuclei selectively catalyzed the acetylation of histones, using acetyl-COA as acetate donor (Bondy et al., 1970). The preparation was most active in acetylating arginine-rich histones. Histone acetylase prepared from nuclei of adult rat brains exhibited greater activity than did similar 
preparations obtained from the brains of newborn rats. In contrast, brain cytoplasmic enzyme was low in both specificity and activity. Treatment of cerebral chromatin with a solubilized acetylase preparation augmented the template activity of the treated chromatin for RNA synthe sis.

Non-enzymatic acetylation of histones has been reported by Paik et al. (1970); however, the reaction occurs almost exclusively in nuclei and has a $\mathrm{pH}$ maximum of 10.0 .

Imoue and Fujimoto (1969) report a histone deacetylating enzyme present in calf thymus extracts. The significance of this enzyme in biological systems, however, is not known.

It is evident from these studies that histone modification is an active process occurring most significantly during periods of enhanced cell growth. Measurement in several systems indicates that histone modification, particularly acetylation, precedes or accompanies increases in DNA-dependent-RNA polymerase activity and RNA synthesis in stimulated cells (Wilhelm and McCarthy, 1970). However, neither direct proof for the involvement of histones nor their modification in the control of RNA synthesis is yet available (Georgiev, 1969; DeLange and Smith, 1971).

\section{HISTONES AND NUCLEAR MECHANISMS}

Butler (1966) proposed a mechanism for the regulation of gene activity involving an interaction between hormone, target protein, and 
histone. According to his model, the hormone, upon reaching its target organ, would be specifically and preferentially bound to a target cell protein with subsequent formation of a protein-hormone complex. This complex would then attach or somehow interact with DNA-associated histone and eithe $r$ remove the histone from the nucleoprotein complex or diminish the degree of binding between DNA and histone. The now derepressed DNA segment would be free to take part in nuclear transcriptional functions. This model becomes most plausible when viewed in light of recent findings that various steroid hormones are capable of increasing DNA template activity, RNA synthesis, and protein synthesis in their respective target organs (Hamilton, 1968; Kenney et al., 1968; Avdalovic and Kochakian, 1969). The biological activity of at least one steroid hormone, estradiol-17- $\beta$, is believed to be initiated by the attachment of hormone to a cytoplasmic "receptor" protein, followed by translocation of the hormone-protein complex into the cell nucleus (Jensen et al., 1968; Mueller, 1971; Truong and Baulieu, 1971). The early actions of this hormone on intact immature and ovariectomized rat uterus is well documented (Teng and Hamilton, 1969; Bresnich, 1971; and Mueller, 1971). It is generally accepted that the action of estradiol on its target organ involves, in part, an activation of nuclear mechanisms for genetic expression (Mueller, 1971). Estradiol may directly affect the template activity of uterine deoxyribonucleoprotein, which is firmly attached to RNA polymerase. 
This action is thought to explain the observed increase in RNA synthesis without an apparent increase in RNA polymerase following estradiol administration (Gorski et al. , 1965).

From 0-24 hours following estradiol treatment, synthesis of ute rine histones remain unchanged. However, at 12-24 hours following hormone treatment, the rate of chromatin-directed RNA synthesis in vitro decreases, whereas RNA levels increase during the latter stages of estrogen action. From the se observations, Gorski et al. (1965) suggest that estradiol may alter the metabolism of ute rine RNA. Teng and Hamilton (1969), investigating the involvement of histones in estrogenic action recently demonstrated that uterine histones, particularly arginine-rich fractions, are capable of inhibiting uterine chromatin-directed RNA synthesis, in vitro. In vivo stimulation of template activity by estradiol-protected RNA synthesis in vitro from the inhibitory effects of added histone. Estradiol, added in vitro at final concentrations of $10^{-5}-10^{-6} \mathrm{M}$, did not protect uterine chromatin-directed RNA synthesis from inhibition by the histones.

The amount of arginine-rich histones in association with ute rine chromatin decreases during the first hour of estradiol administration (Barker, 1971). It is not known whether the histones are metabolized through protolysis or are complexed with non-histone protein. The presence of a specific enzyme capable of degrading histones (histone hydrolase) has been reported in an amphibian system (Paik, 1971). 
Libby (1968) reported the presence of a soluble enzyme present in immature rat uterus, which is capable of acetylating histone. In this study, addition of estradiol in vitro stimulated histone acetylation. The ability of estradiol to stimulate histone acetylation in vivo during the first 15 minutes of hormone treatment has been demonstrated by Libby (1971). However, Anderson and Gorski (1971) reported that, afte $r$ introduction of estradiol, histone acetylation was at first depressed but then rose, beginning at about 12 hours and elevating above control levels at 24 hours following hormone treatment. In their studies with protein methylase, Kaye and Sheratzky (1969) found that estradiol-17$\beta$, preincubated with a $150,000 \times \mathrm{g}$ supernatant fraction of immature rat uterus and then added to a standard assay, decreased the methylation of histone by 10 percent. Furthermore, estradiol-17- $\beta$, administered $50 \mu \mathrm{g} / \mathrm{rat}$, subcutaneously, for 3 days decreased histone methylation by 50 percent, measured in vitro.

Steroid hormones are capable of direct attachment to histones both in vitro and in vivo (Sluyser, 1966; Sunago and Koide, 1967; Sluyser, 1970). The greatest extent of hormonal interaction with histones occurs with arginine-rich histone fractions. The effects of such interactions could be considerable, since histone attachment to DNA may involve lysyl and arginyl histone residues (Lewin, 1970).

The interaction between cortisol-1,2-t and histones is thought to be dependent on the presence of 21 -dehydrocortisol, a contaminant in 
most corticosteroid preparations and the possible active metabolite of cortisol in vivo (DeLange and Smith, 1971). In studies performed by Mander and Walker (1970), cortisol and 21 -dehydrocortisol, a steroid with a glyoxal moiety in its structure, reacted with all histone fractions tested in vitro. Howeve $r$, both steroids were bound most extensively to arginine-rich histones. Blockade of arginyl histone residues by gloxylation (Freedman et al., 1968) greatly diminished binding of 21-dehydrocortisol and eliminated binding of cortisol to the histones. In addition, the results indicate that corticosteroid binding to histones may require prior oxidation of the steroid. The actual binding site may involve covalent interactions between the steroids and residues of the basic amino acids, arginine and lysine, in histone protein. However, the biological significance of these interactions has not been assessed.

\section{GLYOXALS AND THEIR CELLULAR MECHANISMS}

Glyoxals are ketoaldehydes closely related to trioses and other basic metabolites. They reportedly exist endogenously in high concentrations (Szent-Gyorgyi, 1967). Examples of endogenous metabolism leading to the formation of glyoxals include glycine to methylglyoxal and ascorbic acid oxidation to dehydroascorbate (Edgar, 1969). The latter compound contains a glyoxal moiety in its structure and reportedly possesses antitumor properties (Edgar, 1969). Methylglyoxal is metabolized to lactic acid by two closely related enzymes, 
glyoxylase I and glyoxylase II (French and Freelander, 1958). Vince and Wass (1969) a re exploring, the possibility of inhibiting the glyoxylase system in order to potentiate the carcinostatic activity of methylglyoxal.

Szent-Gyorgyi (1968) has proposed that endogenous inhibitors of cell division may include molecular species containing a glyoxal group ( $R-C-C-H)$. In advance of this proposal, Szent-Gyorgyi stated that cells possess an unlimited source of metabolically available electrons but are deficient in electron acceptors. Sulfhydryl groups involved in the complex mechanisms of cell proliferation and protein synthesis would exist in their thiol form and could be oxidized to the disulfide form by glyoxals and thereby be inactivated. In subsequent studies, the glyoxals, particularly methylglyoxal and propylglyoxal, inhibited cell division in both bacterial and mammalian cells (ascites tumor) at concentrations of $10^{-3} \mathrm{M}$ (Egyud and SzentGyorgyi, 1966). Incorporation studies demonstrated that, although protein synthesis was blocked to a greater extent, both DNA and RNA synthesis was inhibited by the glyoxals (Egyud and Szent-Gyorgyi, 1966).

Methylglyoxal and propylglyoxal inhibit cell division in mouse lymphoma (L-5178Y) by their ability to block protein synthesis (Gregg, 1968), whereas glyoxal inhibits DNA synthesis as well as protein synthesis in human fibroblasts (Klamerth, 1968). Scaife (1969) measured ${ }^{3} \mathrm{H}-\mathrm{u}$ ridine incorporation into RNA and ${ }^{3} \mathrm{H}$-thymidine 
incorporation into DNA in human kidney cells grown in monolayer culture and treated with methylglyoxal or Kethoxal ( $\beta$-ethoxy- $\alpha$ ket.o-butyraldehyde). Although DNA, RNA, and protein synthesis were inhibited, the most pronounced effect of these compounds was the blockade of DNA and protein synthesis.

Procaccini et al. (1971) used a soluble rat uterine enzyme to study the inhibition by methylglyoxal and phenylglyoxal of histone acetylation in an in vitro system. They postulated that, if such an inhibitory effect is accomplished in vivo, it might offer an alternate/ additional explanation to the known inhibitory properties of the glyoxals on cell division and proliferation.

Interestingly, two glyoxal derivatives, methylglyoxal-bisguanylhydrazone (Methyl-GAG) and Kethoxal have found limited use in the treatment of leukemia (Freireich et al., 1962; French and Freelander, 1958). However, the exact mechanism of action of these drugs is not yet known (Henderson, 1969). 


\section{EXPERIMENTAL}

\section{A. ANIMALS}

Immature (22-30 day old) female rats (Sprague-Dawley strain;

Charles River Breeding Laboratories, Wilmington, Massachusetts) were housed in quarters maintained at $70^{\circ} \mathrm{C}$ supplied with 12 -hour alte rnating cycle of light and dark. Animals we re offered food (Purina Rat Chow, Ralston Purina Company, St. Louis, Missouri) and water, ad libitum. However, food was removed 24 hours prior to sacrifice in the case of 24-hour time-course studies.

\section{B. SUBCELLULAR FRACTIONATION AND LOCALIZATION OF}

\section{HISTONE ACETYLATING ACTIVITY: SPECIFIC ACTIVITY}

Eight immature (25 day old) female rats were sacrificed by cervical dislocation. The uterine tissue was cleaned of connective tissue, in situ, excised, blotted and weighed. The pooled tissues were homogenized in 9 volumes of $0.25 \mathrm{M}$ cold sucrose solution using a Tri-R homogenizer (Tri-R-Instruments, Rockville Centre, New York). The homogenated were pooled, separated into $15 \mathrm{ml}$ Nalgene centrifuge tubes and centrifuged at $780 \times \mathrm{g}(2,500 \mathrm{RPM})$ for $10 \mathrm{minutes}$ at $0^{\circ} \mathrm{C}$ in a Servall refrigerated centrifuge (Sorvall, Inc., Norwalk, Connecticut). The supernatant was transferred to another set of tubes and centrifuged at $10,000 \times \mathrm{g}(9,500 \mathrm{RPM})$ for 15 minutes. The nuclear fraction was resuspended to volume in $0.25 \mathrm{M}$ sucrose solution and centrifuged 
as before. The resultant supernatant was decanted and discarded, the nuclear pellet was resuspended to volume with Robinson's media (Robinson, 1949), placed in glass screw-cap vials and frozen at $-40^{\circ} \mathrm{C}$ until required for assay. The $10,000 \times \mathrm{g}$ supernatant fraction was transferred to straight-walled plastic centrifuge tubes, capped and centrifuged at $105,000 \times \mathrm{g}(32,000 \mathrm{RPM})$ for 1 hour at $0^{\circ} \mathrm{C}$ in an IEC Preparation Ultracentrifuge (Model B-60, International Equipment Company, Needham Heights, Massachusetts) equipped with an A-170 aluminum head. The mitochondrial fraction was resuspended to volume in $0.25 \mathrm{M}$ sucrose solution and centrifuged at $10,000 \mathrm{xg}$ as before. The resultant supernatant was discarded. The mitochondrial fraction was resuspended to volume in Robinson's media, transferred to screw-cap vials and stored at $-40^{\circ} \mathrm{C}$ until required for assay. The $105,000 \times g$ supernatant fraction was transferred to storage vials and frozen as above. The microsomes were washed twice with $0.25 \mathrm{M}$ sucrose solution, resuspended to volume in Robinson's media, and stored at $-40^{\circ} \mathrm{C}$ until needed for assay. An aliquot of the thawed fraction required for assay of histone acetylation activity was used for protein determinations on all subcellular fractions.

\section{IN VITRO STUDIES}

\section{Temperature study: Determination of temperature coefficient}

$\left(Q_{10}\right)$. Components of the complete assay system previously described were incubated in a Dubnoff metabolic incubator shaker (Dubnoff, 
Precision Scientific Company, Chicago, Illinois) set at $30^{\circ}, 37^{\circ}, 40^{\circ}$, $45^{\circ}, 50^{\circ}, 55^{\circ}$, and $60^{\circ} \mathrm{C}$ for 30 minutes. Histone acetylating activity at the various temperatures was determined. These data were inserted into the van't Hoff equation to determine the $Q_{10}$ value:

$$
\log Q_{10}=\frac{10}{t_{2}-t_{1}} \log \frac{k_{2}}{k_{1}}
$$

where: $\quad k_{2}=$ reaction rate at temperature $t_{2}$

and $k_{1}=$ reaction rate at temperature $t_{1}$

2. Dose response for methyl - and phenylglyoxal: determination of I50. Phenylglyoxal (Pfalz and Bauer) and methylglyoxal (Aldrich Chemical) were dissolved in $0.5 \mathrm{M}$ phosphate buffer, $\mathrm{pH} 7.7$ prior to use. Various concentrations of drugs were preincubated in the presence of enzyme in the assay medium at $37^{\circ} \mathrm{C}$ for 15 minutes; histone was added, and the reaction was allowed to proceed for an additional 30 minutes. The data were plotted $1 \%$ inhibition vs.drug concentration), and the $I_{50}$ value (drug concentration at which 50 percent inhibition is observed) was determined graphically.

\section{Effect of enzyme-drug and histone-drug preincubation bn histone}

acetylation. (a) Enzyme-Drug: Phenylglyoxal was dissolved in $0.05 \mathrm{M}$ phosphate buffer pH 7.7, to a concentration of $10^{-2} \mathrm{M}$. From this stock solution, serial dilutions of $10^{-3} \mathrm{M}$ and $10^{-4} \mathrm{M}$ phenylglyoxal were prepared. A $0.25 \mathrm{ml}$ aliquot of each concentration of phenylglyoxal was transferred to each of three tubes containing $0.25 \mathrm{ml}$ of $10,000 \mathrm{xg}$ 
uterine supernatant $\mathrm{fraction}$ in concentrations of $5 \times 10^{-3} \mathrm{M}, 5 \times 10^{-4} \mathrm{M}$, and $5 \times 10^{-5} \mathrm{M}$ phenylglyoxal, respectively. The contents of the tubes were mixed and incubated at $37^{\circ} \mathrm{C}$. At the end of a 10 minute pre incubation period, a $0.1 \mathrm{ml}$ aliquot of each mixture was transferred to tubes containing all components of the standard assay system with exception of uterine supernatant. The tube contents were mixed and incubated, with shaking, for 20 minutes at $37^{\circ} \mathrm{C}$. Uterine supernatant, preincubated with phosphate buffer constituted the control samples. Standard procedures for the determination of histone acetylation activity were performed on each sample.

(b) Histone-Drug: Solutions of phenylglyoxal at concentrations of $10^{-2} \mathrm{M}, 10^{-3} \mathrm{M}$ and $10^{-4} \mathrm{M}$ were prepared as before. A $0.6 \mathrm{ml}$ aliquot of a freshly prepared solution of calf thymus histone $(10 \mathrm{mg} / \mathrm{ml})$ was added to tubes containing $0.6 \mathrm{ml}$ of phenylglyoxal solution at various concentrations specified. The resultant mixtures, containing phenylglyoxal at concentrations of $5 \times 10^{-3} \mathrm{M}, 5 \times 10^{-4} \mathrm{M}$ and $5 \times 10^{-5} \mathrm{M}$, respectively, were incubated, with shaking, for 10 minutes at $37^{\circ} \mathrm{C}$. Following this period, a $0.2 \mathrm{ml}$ aliquot containing $1.0 \mathrm{mg}$ of histone required for assay was transferred to tubes containing all components of the assay system with the exception of histone. The completed mixture was then incubated for an additional 20 minutes at $37^{\circ} \mathrm{C}$ with shaking. Histone, preincubated with buffer, constituted the controls. Assay of histone acetylating activity of the various samples was accomplished as above. 


\section{IN VIVO STUDIES}

1. Tissue Weight: Alterations with Estradiol and Glyoxals. Immature female rats (26 days old), weighing 70-90 grams, were divided into groups of five animals each. Groups we re housed in plastic box cages furnished with wood chip bedding. Animals were allowed food and water ad libitum. Solutions of drugs in $0.05 \mathrm{M}$ phos phate buffer ( $\mathrm{pH}$ 7.4) were prepared fresh daily and administered according to the following schedule:

(1) phosphate buffer, $1 \mathrm{ml} / \mathrm{kg}$, intraperitoneally, for 6 days, plus $0.2 \mathrm{ml}$ saline subcutaneously, every 12 hours for 60 hours, starting on day 3 of schedule.

(2) phosphate buffer, $1 \mathrm{ml} / \mathrm{kg}$, intraperitoneally, for 6 days, plus estradiol-17- $\beta$ dipropionate (Mann Research Labs) $0.2 \mathrm{ml}$ (12 ug) subcutaneously, every 12 hours for 60 hours, starting on day 3 of schedule.

(3) glyoxal monohydrate, $200 \mathrm{mg} / \mathrm{kg}$, intraperitoneally, daily for 6 days.

(4) glyoxal monohydrate, $200 \mathrm{mg} / \mathrm{kg}$, intraperitoneally, daily for 6 days, plus estradiol, $0.2 \mathrm{ml}$, subcutaneously, every 12 hours for 60 hours, starting on day 3 of schedule.

(5) methylglyoxal-guanylhydrazone (methyl-GAG, Aldrich Chemical) $20 \mathrm{mg} / \mathrm{kg}$, intraperitoneally, daily for 6 days. 
(6) methylglyoxal-guanylhydrazone, $20 \mathrm{mg} / \mathrm{kg}$, intrape ritoneally, daily for 6 days, plus estradiol, $0.2 \mathrm{ml}$, subcutaneously, every 12 hours for 60 hours, starting on day 3 of schedule.

Rats were sacrificed by cervical dislocation. The liver of each animal was perfused in situ with cold $0.25 \mathrm{M}$ sucrose solution, removed, weighed, and placed on ice. The uterus was surgically cleaned of connective tissue, excised, press blotted and weighed. The liver and uterus from each animal was homogenized separately in 9 volumes of Robinson's medium (Robinson, 1949), using a Polytron homogenizer (Speed \#6 for 15 sec.), followed by centrifugation at $10,000 \times \mathrm{g}$ (9,500 RPM) for 10 minutes at $0^{\circ} \mathrm{C}$ in a Servall Refrigerated Centrifuge (Sorval, Model RC2-B). The supernatant fraction of liver and ute rus was transferred in $1.0 \mathrm{ml}$ aliquots to $5 \mathrm{ml}$ glass screw-cap vials and stored at $-40^{\circ} \mathrm{C}$ until required for enzymatic as say.

2. Estradiol and Phenylglyoxal: Initial response. A stock solution of estradiol-17- $\beta$ (Scwartz-Mann) was prepared by dissolving $25 \mathrm{mg}$ of the hormone in $100 \mathrm{ml}$ of $95 \%$ ethyl alcohol. At the time of administration, $1.0 \mathrm{ml}$ of ethanolic stock solution was slowly added to 3. $0 \mathrm{ml}$ of saline with constant stirring to prepare a suspension containing $60 \mu \mathrm{g} / \mathrm{mll}$ of estradiol. At the time of injection (treatment 2) each rat received approximately $12 \mu \mathrm{g}$ of estradiol $(0.2 \mathrm{ml})$ subcutaneously. A freshly prepared solution of phenylglyoxal monohydrate in $0.05 \mathrm{M}$ phosphate buffer was adjusted to $\mathrm{pH} 7.4$ with $0.5 \mathrm{~N} \mathrm{NaOH}$. 
Four groups of eight, 26-day old female rats were administered phenylglyoxal, $250 \mathrm{mg} / \mathrm{kg}$, intraperitoneally (Treatment 1 ). At the end of one hour, each animal received estradiol, $12 \mu \mathrm{g} / \mathrm{rat}$, subcutaneously (Treatment 2). Groups receiving estradiol, following phenylglyoxal pretreatment or estradiol alone, were sacrificed at $0,5,10$, and 15 minutes following estradiol treatment. Control animals receiving $1 \mathrm{ml} / \mathrm{kg}$ of $0.05 \mathrm{M}$ phosphate buffer alone were sacrificed one hour following injection. Rats were sacrificed by cervical dislocation. Individual uterine tissue was press blotted, and weighed, and the pooled tissues from two identically treated animals were homogenized in 9 volumes of cold Robinson's media. The $10,000 \times \mathrm{g}$ supernatant fractions were stored at $-40^{\circ} \mathrm{C}$ in $5 \mathrm{ml}$ glass screw-cap vials until required for assay. Protein determinations of the supernatant fractions obtained from experimental groups were carried out by the method of Lowry et al. (1951). Students " $t$ " test was employed to determine statistical differences between treated and untreated groups.

\section{Activity of Estradiol and Glyoxals: Time response.}

Immature (25 day old) female rats were divided into groups of 6 to 8 animals. Control groups received $1 \mathrm{ml} / \mathrm{kg}$ of the drug vehicle, $0.05 \mathrm{M}$ phosphate buffer ( $\mathrm{pH}$ 7.4) or estradiol vehicle. Rats were administered either estradiol-17- $\beta, 10 \mathrm{ug} / \mathrm{rat}$, intraperitoneally, or phenylglyoxal, $250 \mathrm{mg} / \mathrm{kg}$, intraperitoneally. Animals treated with either drug were sacrificed at $1,2,4,8,16$, and 24 hours following drug administration. 
Rats were sacrificed by cervical dislocation. The uterine tissue was surgically cleaned, blotted and weighed. For histone acetylation studies, tissues from two rats were pooled and homogenized in 9 volumes of Robinson's media. Further preparation and storage of the ute rine extract for subsequent analysis of histone acetylation activity was as described previously.

4. Drug Interaction: Estradiol and Glyoxals. Thirty day old female rats we re divided into groups of 8 to 10 animals. Rats were administered estradiol, $10 \mathrm{ug} / \mathrm{rat}$, intraperitoneally. Control animals received estradiol vehicle as described previously. At 20 hours following hormone treatment, estradiol treated rats received either methylglyoxal (125 mg/kg or $250 \mathrm{mg} / \mathrm{kg}$ ) or phenylglyoxal (250 mg/kg), intraperitoneally. Vehicle treated rats also received the same doses of the glyoxals. Control rats received $1 \mathrm{ml} / \mathrm{kg}$ of the drug vehicle, $0.05 \mathrm{M}$ phosphate buffer $(\mathrm{pH} 7.4)$. Groups of animals were injected at appropriate intervals in order to account for the time required for sacrifice of each group. All animals were sacrificed 24 hours after estradiol administration ( 4 hours following glyoxal administration). Protocol followed after sacrifice, involving weighing, uterine extract preparation and assay were as described previously except that tissues from this study were not pooled. Protein determinations were carried out by the method of Lowry et al. (1951). 


\section{E. ASSAY OF HISTONE ACETYLATION}

The procedure for the analysis of histone acetylation is a modification of the method of Libby (1968). A $0.05 \mathrm{ml}$ aliquot of a 10,000 $\mathbf{x} \mathrm{g}$ supernatant fraction of rat uterus (prepared as previously described) capable of acetylating histones was routinely employed as the enzyme source in the assay system. The assay mixture contained, in addition to the supernatant fraction, 100 umoles of phosphate buffer (pH 7. 7), 5 umoles ATP (Sigma Chemical Company) solution adjusted to neutrality with $0.5 \mathrm{~N} \mathrm{NaOH}, 0.05$ umoles coenzyme A (Cal-Biochem), 5u C Na-acetate-1- ${ }^{14} \mathrm{C}$ (New England Nuclear; specific activities of 57-60 millicuries/millimole); and $1.0 \mathrm{mg}$ calf thymus histone (Worthington Biochemicals and enough distilled wate $r$ to make a final volume of 1.0 $\mathrm{ml}$. Components of the incubation mixture were pipetted into $15 \mathrm{ml}$ Nalgene tubes. All drug preparations were made in the buffer used for enzyme incubations. Incubations were carried out in a Dubnoff metabolic shaker at $37^{\circ} \mathrm{C}$ under air. Following the prescribed incubation time, the reaction was terminated by the addition of $5 \mathrm{ml}$ of cold acetone. The tubes were sealed with Parafilm (American Can Company, Neenan, Wisconsin), mixed by inversion and allowed to stand in a freezer at $-40^{\circ} \mathrm{C}$ for approximately 30 minutes. The tubes were then centrifuged for 10 minutes at $10,000 \times \mathrm{g}$ in a Sorval Model $\mathrm{RC} 2-\mathrm{B}$ refrigerated centrifuge at $0^{\circ} \mathrm{C}$. The resultant aqueous-acetone supernatant was decanted and discarded and the tubes inverted and allowed to dry. Drying was usually complete in $30-40$ minutes. The 
precipitate was resuspended in $1.0 \mathrm{ml}$ of $0.2 \mathrm{~N} \mathrm{H}_{2} \mathrm{SO}_{4}$ by mixing in a Vortex mixer for 10 seconds, and the tubes were allowed to stand at room temperature for 20 minutes. The tubes were then centrifuged at $10,000 \times \mathrm{g}$ for 10 minutes and the resultant supernatant was carefully decanted into another set of Nalgene tubes. After the addition of $5 \mathrm{ml}$ of cold acetone, the tubes were mixed by inversion, as before, and allowed to stand in a freezer for approximately 30 minutes. The tubes were centrifuged for 10 minutes at $10,000 \times \mathrm{g}$ and the supernatant discarded. One $\mathrm{ml}$ of $0.05 \mathrm{M}$ barbital buffer, $7.5 \mathrm{M}$ in urea ( $\mathrm{pH} 9.0$ ), was added to the precipitate and mixed on a Vortex mixer for 10 seconds. The tubes were allowed to stand at room temperature for 15-20 minutes at which time $0.5 \mathrm{ml}$ of this solution was transferred to glass counting vials containing $15 \mathrm{ml}$ of a scintillation cocktail which was prepared by dissolving $4 \mathrm{~g}$ of 2-5-diphenyloxazole (PPO) plus $50 \mathrm{mg}$ of 1,4-phenylene-bio-2-(5-phenyloxazole) in $700 \mathrm{ml}$ of toluene plus $300 \mathrm{ml}$ of BBS-3 (Bio-Solv, Beckman Instruments, Inc.). The vials were counted in a Packard Tri-Carb Liquid Scintillation Spectromete $r$ at a counting efficiency of approximately $70 \%$, as determined by quench correction series.

\section{F. PROTEIN DETERMINATION}

Protein content of whole homogenate, subcellular fractions and $10,000 \times \mathrm{g}$ supernatant was determined by the method of Lowry et al. (1951). A $0.2 \mathrm{ml}$ sample of the fraction to be assayed was added to 
tubes containing $0.8 \mathrm{ml}$ of $0.5 \mathrm{~N} \mathrm{NaOH}$. Protein standards at concentrations of $0.5,1.0$ and $1.5 \mathrm{mg} / \mathrm{ml}$ we re prepared using bovine plasma albumin (Calbiochem). Reagent blanks containing $0.2 \mathrm{ml}$ of Robinson's media were treated identically as tissue samples. The tubes were stoppered and placed in a hot water bath for 1 hour maintained at $70-75^{\circ} \mathrm{C}$. The samples were cooled by immersion in cold tap water. A $0.2 \mathrm{ml}$ aliquot of the boiled sample was added to $0.8 \mathrm{ml}$ of $0.5 \mathrm{~N} \mathrm{NaOH}$ and $5.0 \mathrm{ml}$ of Reagent $\mathrm{A}^{\mathrm{a}}$. The samples were mixed on a Vortex mixer and allowed to stand for 20 minutes at room temperature. Following this, $0.5 \mathrm{ml}$ of Reagent $\mathrm{B}^{\mathrm{b}}$ was added to each sample, mixed immediately and allowed to stand at room temperature for 40 minutes, until color development was complete. The absorbance at $500 \mathrm{~nm}$ was read against the reagent blank on a Beckman DB-Spectrophotometer (Beckman Instruments).

\section{G. EXTRACTION OF NUCLEIC ACIDS}

The method of Schneider (1945) for the extraction of nucleic acids and the measurement of DNA was used.

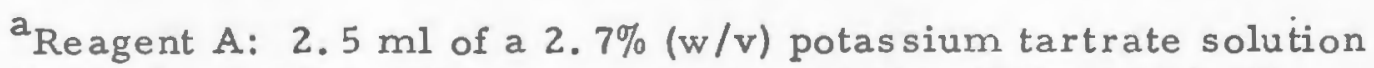
and $2.5 \mathrm{ml}$ of a $1.0 \%(\mathrm{w} / \mathrm{v})$ copper sulfate added to $250 \mathrm{ml}$ of $2.0 \%$ $(\mathrm{w} / \mathrm{v})$ sodium carbonate solution.

${ }^{b}$ Reagent $B$ : Commercial folin-phenol reagent diluted to $1 \mathrm{~N}$ with distilled water. 
A $0.7 \mathrm{ml}$ aliquot of a 10 percent rat uterine whole homogenate was mixed (Vortex) with $2.5 \mathrm{ml}$ cold 10 percent trichloracetic acid (TCA) in $15 \mathrm{ml}$ Corex glass tube and centrifuged in an IEC Clinical Centrifuge at 1000 RPM for six minutes. The supernatant was decanted and discarded and the precipitate resuspended in $2.5 \mathrm{ml}$ of cold 10 percent TCA. The tubes were centrifuged as above, and the supernatant was decanted and discarded. This procedure is used to remove acid-soluble phosphorus compounds.

The tissue residue was suspended in $1.0 \mathrm{ml}$ of distilled water by Vortex mix for 10 seconds, and $4.0 \mathrm{ml}$ of 95 percent ethyl alcohol and centrifuged. The supernatant was decanted and discarded, and the residue was resuspended in $5.0 \mathrm{ml}$ of 95 percent E.TOH. The supernatant was decanted and discarded. These steps are used to remove traces of TCA from the residue.

The tissue residue was boiled 3 times for 3 minutes each with 5.0 ml portions of an alcohol-ether mixture (3:1). A small boiling chip was added to each tube in order to facilitate even boiling. The tubes were centrifuged as before following each boiling and the supe rnatant was decanted and discarded. This procedure was employed to remove phospholipids.

The tissue residue was suspended in $1.3 \mathrm{ml}$ of distilled.water mixed with $1.3 \mathrm{ml}$ cold 10 percent TCA and centrifuged. The supernate was decanted and discarded. 
The tissue residue was resuspended in $5.0 \mathrm{ml}$ of 5 percent TCA, and the tubes were heated for 15 minutes in a water bath at $90^{\circ} \mathrm{C}$. The tubes were centrifuged and the supernatant was decanted and saved.

The tissue residue was resuspended in $2.5 \mathrm{ml}$ of 5 percent TCA and centrifuged. The TCA extracts were combined $(7.5 \mathrm{ml})$ to form the nucleic acid extract.

\section{H. ESTIMATION OF DNA}

One $\mathrm{ml}$ of the nucleic acid extract was mixed with $2.0 \mathrm{ml}$ of diphenylamine reagent ${ }^{a}$ and heated in a boiling water bath for 10 minutes at $90^{\circ} \mathrm{C}$. The intensity of blue color was read at $600 \mathrm{~nm}$.

DNA standard solutions we re prepared in concentrations ranging from $20 \mu \mathrm{g} / \mathrm{ml}$ to $200 \mu \mathrm{g} / \mathrm{ml}$ by dissolving $10 \mathrm{mg}$ of highly polyme rized DNA in $25 \mathrm{ml}$ of 5 percent TCA, and diluting to the desired concentrations. A reagent blank of 5 percent TCA was used.

\section{ESTIMATION OF RNA}

The method of Ceriotti (1955) was used for the measurement of RNA. Five $\mathrm{ml}$ of the nucleic extract was added to $5.0 \mathrm{ml}$ of freshly prepared orcinol reagent ${ }^{\mathrm{b}}$ in $15 \mathrm{ml}$ screw-cap tubes. The samples were

${ }^{a}$ Diphenylamine Reagent: $1 \mathrm{gm}$ of diphenylamine which is recrystallized in boiling hexane is dissolved in $100 \mathrm{ml}$ of glacial acetic acid (analytical reagent) and $2.75 \mathrm{ml}$ of reagent concentrated sulfuric acid is added.

borcinol Reagent: $200 \mathrm{mg}$ of purified orcinol is dissolved in concentrated $\mathrm{HCL}$; add $10 \mathrm{ml}$ of $\mathrm{CuCL}_{2}$ reagent $10.004 \mathrm{M} \mathrm{CuCL} 2$ in concentrated HCL: $68.2 \mathrm{mg} \mathrm{CuCL} / 100 \mathrm{ml} \mathrm{HCL}$ ) and make up to $100 \mathrm{ml}$ with concentrated HCL. 
mixed thoroughly and the tubes placed in a boiling water bath for 40 minutes. After cooling with running water, the color was extracted into $5.0 \mathrm{ml}$ of isoamyl alcohol with shaking (Buchler Instruments, New Jersey). The tubes were centrifuged and a $3.0 \mathrm{ml}$ aliquot of the isoamyl alcohol layer, containing the chromophor, was pipetted into an additional series of tubes. The absorbance at $675 \mathrm{~nm}$ was determined. RNA standard solutions were prepared by dissolving RNA in 5 percent TCA over low heat. The isoamyl alcohol layer taken from the tube containing no RNA was used as the blank.

\section{J. STATISTICAL METHODS}

The 2 -tailed students " $t$ " test for independent means, calculated on an Olivetti Underwood Programma 101 desk computer, was used to test for differences between means. The formula employed is as follows:

$$
t=\frac{\bar{x}_{1}-\bar{x}_{2}}{s_{p}\left(1 / N_{1}\right)+\left(1 / N_{2}\right)}
$$

where:

$$
\mathrm{S}_{\mathrm{p}}^{2}=\frac{\left(\mathrm{N}_{1}-1\right) \mathrm{S}_{1}^{2}+\left(\mathrm{N}_{2}-1\right) \mathrm{S}_{2}^{2}}{\mathrm{~N}_{1}+\mathrm{N}_{2}-2}
$$

$$
\begin{aligned}
N_{1} & =\text { Control sample size } & \mathrm{S}_{2}{ }^{2} & =\text { Treated sample variance } \\
\mathrm{N}_{2} & =\text { Treated sample size } & \overline{\mathrm{X}}_{1} & =\text { Control sample mean } \\
\mathrm{S}_{1}{ }^{2} & =\text { Control sample variance } & \overrightarrow{\mathrm{X}}_{2} & =\text { Treated sample mean }
\end{aligned}
$$

The degrees of freedom were taken as $\mathrm{N}_{1}+\mathrm{N}_{2}-2$. The level of significance $(P)$ was determined by comparison of " $t$ " with values from standard tables. 


\section{RESULTS}

The $10,000 \times g$ supernatant fraction of rat uterine tissue was employed as the histone acetylating system throughout the study (Appendix A and B).

Various concentrations of methylglyoxal and phenylglyoxal were preincubated in a standard assay system for 15 minutes. Histone was added and the reaction was allowed to proceed for an additional 30 minutes. Under these conditions, as shown in Figure 1, both phenylglyoxal and methylglyoxal inhibited in vitro histone acetylation in a concentration dependent manner. Drug concentrations of $2 \times 10^{-4} \mathrm{M}$ to $1 \times 10^{-3} \mathrm{M}$ depressed in vitro histone acetylation approximately 25 percent to 75 percent, respectively (Figure 1). The $I_{50}$ for methylglyoxal was $0.5 \mathrm{mM}$, and $0.4 \mathrm{mM}$ for phenylglyoxal (Table 1).

The in vitro effect of incubating phenylglyoxal with the uterine histone acetylation preparation prior to assay is shown in Table 2 . Following a 10 minute incubation period, an aliquot of the preincubation system containing enzyme and drug was introduced into a standard assay system. The reaction was allowed to proceed for 20 minutes. Under these conditions, approximately 80 percent inhibition was achieved at $5 \times 10^{-4} \mathrm{M}$ assay system concentration, below which level no significant degree of enzyme inhibition was noted. The results of a parallel study, designed to determine the effect of phenylglyoxal 


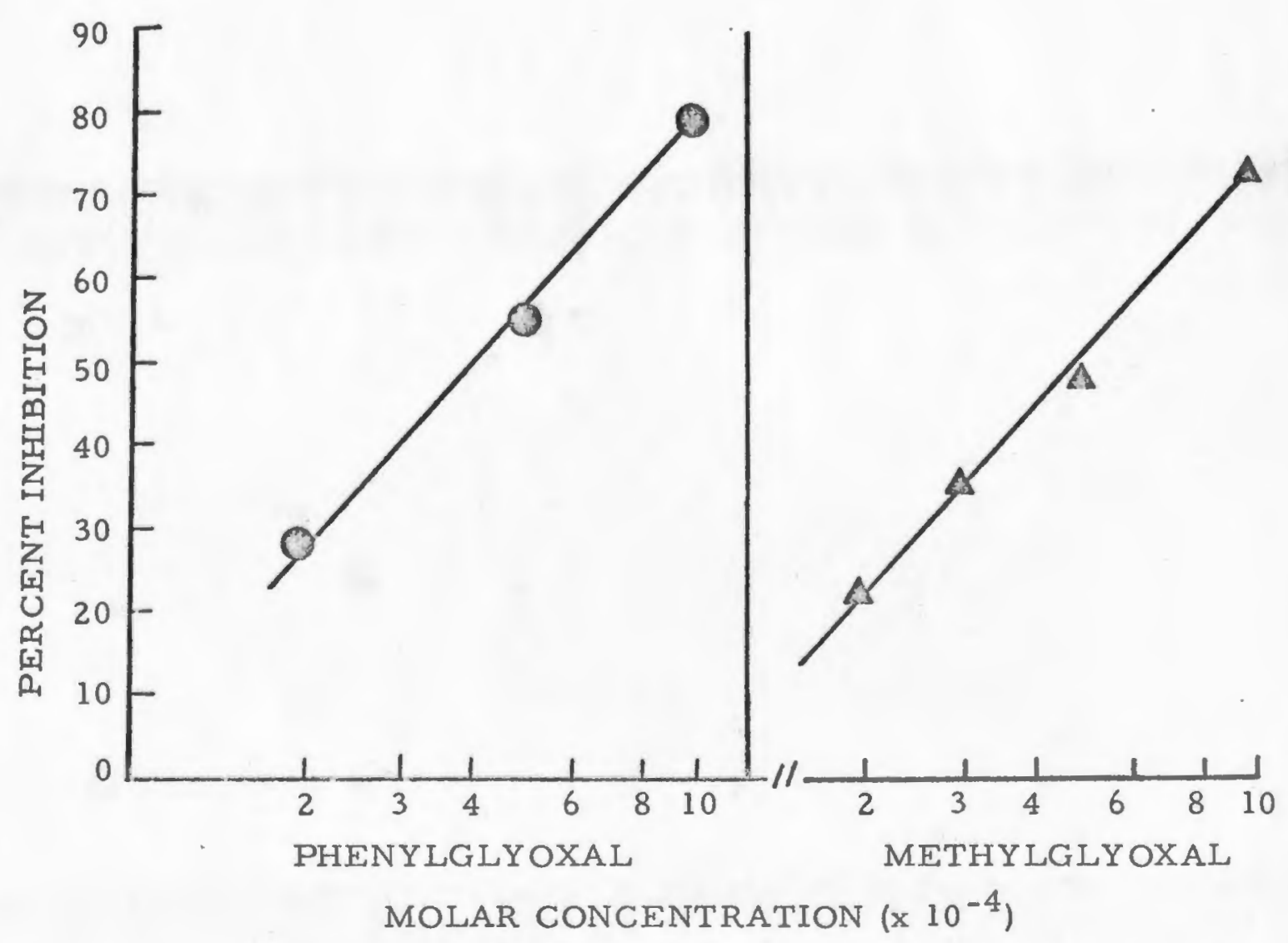

Figure 1: Effect of (a) phenylglyoxal and (b) methylglyoxal on in vitro histone acetylation by a cell-free rat uterine system. Freshly prepared solutions of glyoxals were added at various concentrations and preincubated for 15 minutes at $37^{\circ} \mathrm{C}$ prior to the addition of histone. The reaction was allowed to proceed for an additional 30 minutes. Each point represents at least three determinations. 
Table 1. Inhibition of in vitro histone acetylation by glyoxal de rivatives: Index of inhibition (I 50 value $)^{a}$

\begin{tabular}{lc}
\hline Compound & $I_{50}$ Value \\
\hline Methylglyoxal & $0.5 \mathrm{mM}$ \\
Phenylglyoxal & $0.4 \mathrm{mM}$ \\
\hline
\end{tabular}

${ }^{a}$ The approximate concentration of drug at which 50 percent inhibition is observed. Various concentrations of inhibitors were preincubated for $15 \mathrm{~min}$ at $37^{\circ} \mathrm{C}$ prior to addition of $1 \mathrm{mg}$ calf thymus histone. The data was plotted and $I_{50}$ values graphically determined. 
Table 2. In vitro inhibition of histone acetylation: Effect of phenylglyoxal-enzyme preincubation

\begin{tabular}{|c|c|c|c|}
\hline \multicolumn{2}{|c|}{ Phenylglyoxal Concentration (Final) } & \multirow{2}{*}{$\begin{array}{c}\text { Histone Acetylation } \\
\mathrm{dpm} / \mathrm{mg} \text { Histone } \\
\text { Mean I S.E. }\end{array}$} & \multirow[b]{2}{*}{$\begin{array}{l}\text { Percent } \\
\text { Inhibition }\end{array}$} \\
\hline $\begin{array}{c}\text { Preincubation } \\
\text { System }^{2}\end{array}$ & $\begin{array}{l}\text { Assay b } \\
\text { System }\end{array}$ & & \\
\hline--- & $-\cdots$ & $22,140 \pm 300$ & control \\
\hline $5.0 \times 10^{-3} \mathrm{M}$ & $5.0 \times 10^{-4} \mathrm{M}$ & $4,902 \pm 591$ & 78 \\
\hline $5.0 \times 10^{-4} \mathrm{M}$ & $5.0 \times 10^{-5} \mathrm{M}$ & $20,117 \pm 1521$ & 10 \\
\hline $5.0 \times 10^{-5} \mathrm{M}$ & $5.0 \times 10^{-6} \mathrm{M}$ & $22,317 \pm 1011$ & 0 \\
\hline
\end{tabular}

a Phenylglyoxal solutions of appropriate concentrations were incubated with $0.25 \mathrm{ml}$ aliquots of $10,000 \mathrm{xg}$ rat uterine supernatant fraction at $37^{\circ} \mathrm{C}$ for $10 \mathrm{~min}$ with shaking.

${ }^{\mathrm{b}}$ Following preincubation (a), a $0.1 \mathrm{ml}$ aliquot of the phenylglyoxalenzyme mixture (equivalent to $0.05 \mathrm{ml}$ supernatant) was added to tubes containing $0.9 \mathrm{ml}$ of standard assay system components, less supernatant. The completed system was then incubated at $37^{\circ} \mathrm{C}$, wi th shaking, for $20 \mathrm{~min}$.

* Mean \pm S.E. of triplicate determinations. 
incubation with histone are presented in Table 3. In this study, a $5 \times 10^{-4} \mathrm{M}$ phenylglyoxal as say system concentration inhibited in vitro histone acetylation by approximately 30 percent. Inhibition of histone acetylation was not evident at a concentration of $5 \times 10^{-6} \mathrm{M}$ phenylglyoxal.

The effect of glyoxals on ute rine weight and total body weight gains in immature rats was explored by administering daily injections of methylglyoxal-bis-guanylhydrazone (Methyl-GAG, $20 \mathrm{mg} / \mathrm{kg}$, intraperitoneally) and glyoxal monohydrate $(200 \mathrm{mg} / \mathrm{kg}$, intraperitoneally) for six days. The increase in total body weight over the six day treatment period was also studied. Results of this study are presented in Table 4. Animals receiving glyoxal monohydrate gained significantly less weight $(P<0.05)$ than did the control animals. Uterine wet weight of glyoxal treated animals was approximately 50 percent of vehicle treated controls. This alteration was reflected when the data was expressed as uterine/body weight ratio. This value was employed to account for variation in tissue weight that may be due to body weight differences in animals from any experimental group. No difference $(P>0.05)$ in net body weight gain was observed in animals receiving Methyl-GAG, $20 \mathrm{mg} / \mathrm{kg}$, intraperitoneally, for six days when compared to controls. However, uterine wet weight of Methyl-GAG treated animals was depressed $(P<0.025)$, but to an extent less than that noted in the glyoxal treated group. This alteration was also reflected 
Table 3. In vitro inhibition of histone acetylation: Effect of phenylglyoxal-histone preincubation

\begin{tabular}{|c|c|c|c|}
\hline \multicolumn{2}{|c|}{ Phenylglyoxal Concentration (Final) } & \multirow{2}{*}{$\begin{array}{c}\text { Histone Acetylation } \\
\text { dpm/mg Histone } \\
\text { Mean } \pm \text { S.E. }\end{array}$} & \multirow[b]{2}{*}{$\begin{array}{l}\text { Percent } \\
\text { Inhibition }\end{array}$} \\
\hline $\begin{array}{c}\text { Preincubation } \\
\text { System }\end{array}$ & $\begin{array}{l}\text { Assay } \\
\text { Systemb }\end{array}$ & & \\
\hline$-\cdots$ & $\ldots-$ & $26,553 \pm 3666$ & control \\
\hline $5.0 \times 10^{-3} \mathrm{M}$ & $5.0 \times 10^{-4} \mathrm{M}$ & $18,303 \pm 4378$ & 32 \\
\hline $5.0 \times 10^{-4} \mathrm{M}$ & $5.0 \times 10^{-5} \mathrm{M}$ & $22,700 \pm 1255$ & 15 \\
\hline $5.0 \times 10^{-5} \mathrm{M}$ & $5.0 \times 10^{-6} \mathrm{M}$ & $26,740 \pm 1691$ & 0 \\
\hline
\end{tabular}

${ }^{a} 0.6 \mathrm{ml}$ histone solution $(10 \mathrm{mg} / \mathrm{ml})$ was added to $0.6 \mathrm{ml}$ of phenylglyoxal solution of various concentrations, or $0.6 \mathrm{ml}$ of phenylglyoxal vehicle (phosphate buffer) for control assays and the mixture was incubated with shaking for $10 \mathrm{~min}$ at $37^{\circ} \mathrm{C}$.

${ }^{b}$ Following preincubation period, a $0.2 \mathrm{ml}$ aliquot of phenylglyoxalhistone mixture (equivalent to $1 \mathrm{mg}$ histone) was added to tubes containing $0.8 \mathrm{ml}$ of.standard assay system components, less histone. The complete system was then incubated at $37^{\circ} \mathrm{C}$ for an additional $20 \mathrm{~min}$.

* Mean \pm S.E. of triplicate determinations. 
Table 4. Effect of glyoxal derivatives on body weight and uterine wet weight in immature female rats

\begin{tabular}{|c|c|c|c|}
\hline Treatment ${ }^{a}$ & $\begin{array}{c}\text { Body Weight } \\
\text { Increase (gm) } \\
\text { Mean } \pm \text { S.E. (N) }\end{array}$ & $\begin{array}{c}\text { Uterine Wet } \\
\text { Weight (mg) } \\
\text { Mean } \pm \text { S.E. (N) }\end{array}$ & $\begin{array}{c}\text { Uterine / Body } \\
\text { Ratio }(\%) \\
\text { Mean } \pm \text { S.E. (N) }\end{array}$ \\
\hline Control & $34.4 \pm 3.1$ (5) & $152 \pm 15(5)$ & $0.140 \pm .014(5)$ \\
\hline Glyoxal & $\begin{array}{c}21.2 \pm 3.6(4) \\
(P<.05)^{*}\end{array}$ & $\begin{array}{l}68 \pm 5(4) \\
(P<.001)^{*}\end{array}$ & $\begin{array}{c}0.065 \pm .004(4) \\
(P<.0025)^{*}\end{array}$ \\
\hline Methyl-GAG & $\begin{array}{c}32.0 \pm 2.9(5) \\
(P>.05)^{*}\end{array}$ & $\begin{array}{l}107 \pm 8(5) \\
(P<.025)^{*}\end{array}$ & $\begin{array}{c}0.092 \pm .008(5) \\
(P<.01)^{*}\end{array}$ \\
\hline
\end{tabular}

${ }^{a}$ Control: $1 \mathrm{ml} / \mathrm{kg}$, i. p., 0.5M phosphate buffer (pH 7.4) daily for 6 days; Glyoxal: $200 \mathrm{mg} / \mathrm{kg}$, i.p. ; and Methylglyoxal-bis-guanylhydrazone (Methyl-GAG), $200 \mathrm{mg} / \mathrm{kg}$, i.p. , daily for 6 days.

${ }^{\mathrm{b}}$ Mean body weight gain during 6 day experimental period.

*Determined by Student " $t$ " test. 
in the uterine/body weight ratio, indicating that the alteration was not due to inherent tissue weight differences attributable to variations in total body weight alone.

In order to determine the effect of prior glyoxal treatment in animals receiving estradiol alone, several groups of rats were given daily injections of glyoxal, $200 \mathrm{mg} / \mathrm{kg}$, intraperitoneally, or MethylGAG, $20 \mathrm{mg} / \mathrm{kg}$, intraperitoneally, for six days. In addition, estradiol $12 \mu \mathrm{g} / \mathrm{rat}$ was administered subcutaneously every 12 hours for 60 hours beginning day three of treatment. The comparison of effect of estradiol alone or in animals pretreated with glyoxals is presented in Table 5. Uterine/body weight ratios of animals receiving either glyoxal or Methyl-GAG.prior to estradiol administration were significantly lower $(P<0.005)$ than were comparable values obtained from animals receiving estradiol alone. No significant differences were observed in the liver/body weight ratio of animals receiving estradiol alone or in combination with either glyoxal or Methyl-GAG.

The early effect of estradiol administration on histone acetylation activity in immature rat uterus was explored by sacrificing groups of hormone treated animals at $0,5,10$ and 15 minutes following injection of estradiol, $12 \mu \mathrm{g} / \mathrm{rat}$, subcutaneously. The soluble ute rine histone acetylation fraction was subsequently prepared (as described previously) and the enzyme activity determined (Figure 2). In addition, a second series of animals received phenylglyoxal, $250 \mathrm{mg} / \mathrm{kg}$, intraperitoneally, 1 hour prior to estradiol administration, in order to determine the 
Table 5. Effect of combined glyoxal and Methyl-GAG with estradiol administration on uterus/body ratio and liver/body ratio in immature female rats: Comparison between glyoxal pretreated and estradiol treated animals

\begin{tabular}{|c|c|c|}
\hline Treatment ${ }^{a}$ & $\begin{array}{l}\text { Uterus / Body Ratio (\%) } \\
\text { Mean IS.E. (N) }\end{array}$ & $\begin{array}{c}\text { Liver/Body Ratio (\%) } \\
\text { Mean IS.E. (N) }\end{array}$ \\
\hline Estradiol-17- $\beta$ & $0.197 \pm 0.006(5)$ & $5.51 \pm 0.21(5)$ \\
\hline $\begin{array}{l}\text { Glyoxal plus } \\
\text { Estradiol }\end{array}$ & $\begin{array}{l}0.104 \pm 0.006(5) \\
(P<.005) *\end{array}$ & $\begin{array}{l}6.17 \pm 0.29(5) \\
(P>.05)^{*}\end{array}$ \\
\hline $\begin{array}{l}\text { Methyl-GAG plus } \\
\text { Estradiol }\end{array}$ & $\begin{array}{l}0.147 \pm 0.010(5) \\
(P<.005)^{*}\end{array}$ & $\begin{array}{c}5.09 \pm 0.35(5) \\
(P>.05)^{*}\end{array}$ \\
\hline \multicolumn{3}{|c|}{ 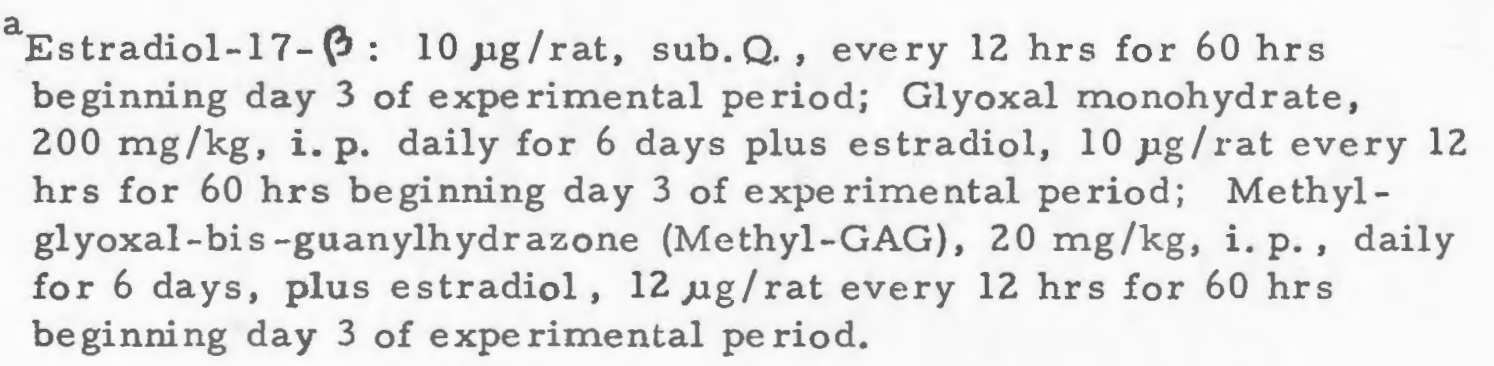 } \\
\hline
\end{tabular}




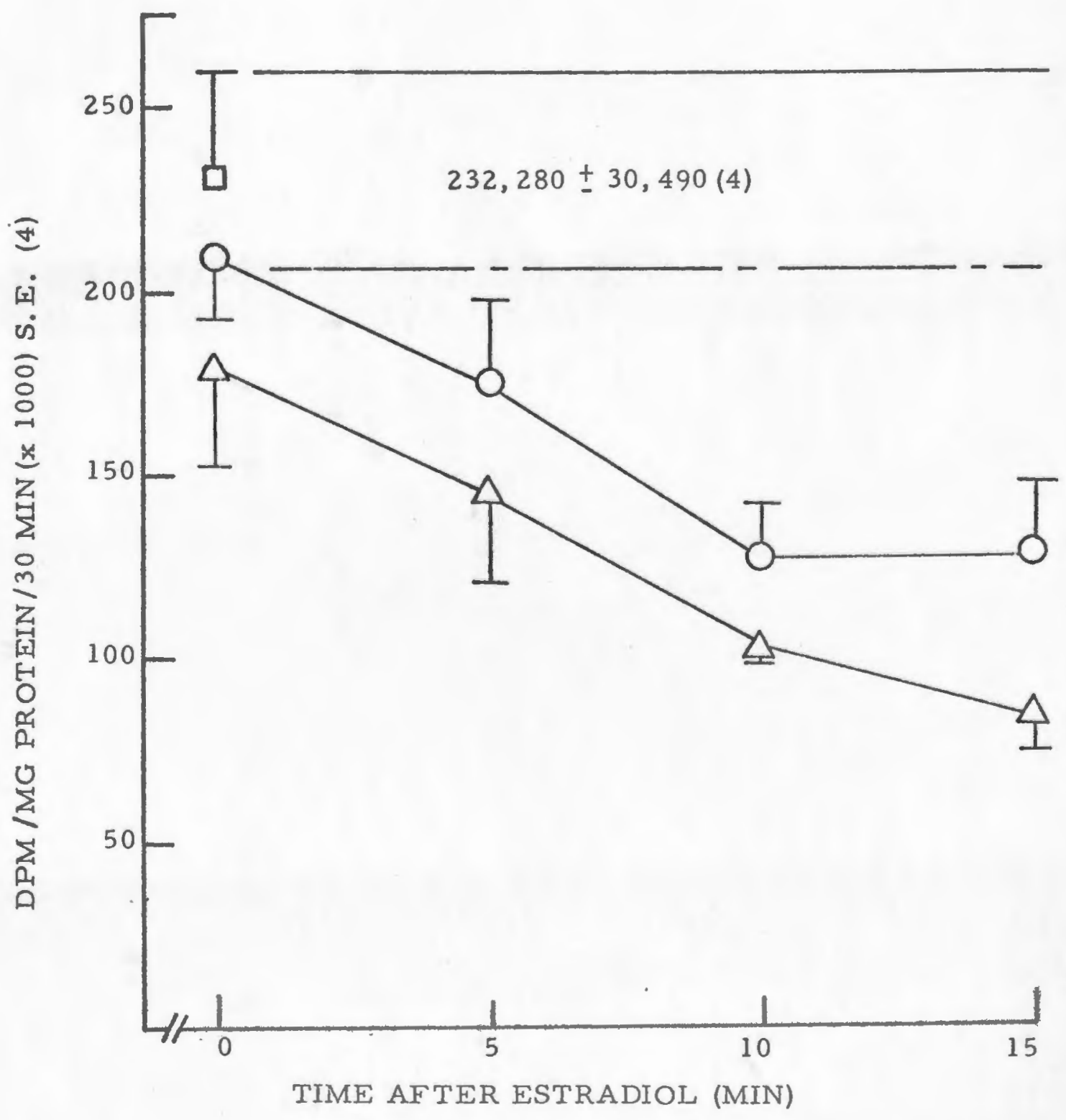

Figure 2: Histone acetylation in soluble uterine fraction from rats treated with estradiol alone and in combination with phenylglyoxal. Rats were administered either $1 \mathrm{ml} / \mathrm{kg}$ of $0.05 \mathrm{M}$ phosphate buffer vehicle (D); estradiol, $12 \mu \mathrm{g} / \mathrm{rat}$, sub-Q, (O-O); or phenylglyoxal, $250 \mathrm{mk} / \mathrm{kg}$, i. p. , for 1 hour followed by estradiol $(\Delta-\Delta)$. Rats were killed at the time intervals indicated and soluble uterine enzyme activity measured. 
effect of phenylglyoxal pretreatment on any early hormone-mediated alterations in uterine histone acetylation. Enzyme activity was significantly depressed $(P<.05)$ when measured 10 and 15 minutes following estradiol treatment. A further decrease in enzyme activity was noted in animals pretreated with phenylglyoxal one hour prior to estradiol administration. The differences seen with estradiol treatment alone were significantly different $(P<0.05)$ from phenylglyoxal pretreated animals given estradiol for 15 minutes.

The in vivo effect of estradiol on ute rine wet weight and histone acetylation in immature female rats was monitored at $1,2,4,8,16$, and 24 hours following hormone treatment. In addition, a parallel study was performed using phenylglyoxal, $250 \mathrm{mg} / \mathrm{kg}$, intraperitoneally, in order to determine the time course of the early phenylglyoxal mediated decrease in uterine histone acetylation noted in the previous study. The alterations in histone acetylation activity following estradiol and phenylglyoxal administration are presented in Figure 3. A very rapid estradiol mediated decrease in the ability of the uterine enzyme preparation to acetylate histone was found to occur following hormone administration. Enzyme activity remained almost completely depressed until 8 hours after estradiol administration, when enzyme activity began to increase during an 8 to 12 hour period. During 16 to 24 hours, the initial effect of the hormone was reversed, so that at 24 hours post estradiol, enzyme activity was increased to 135 percent of control. 


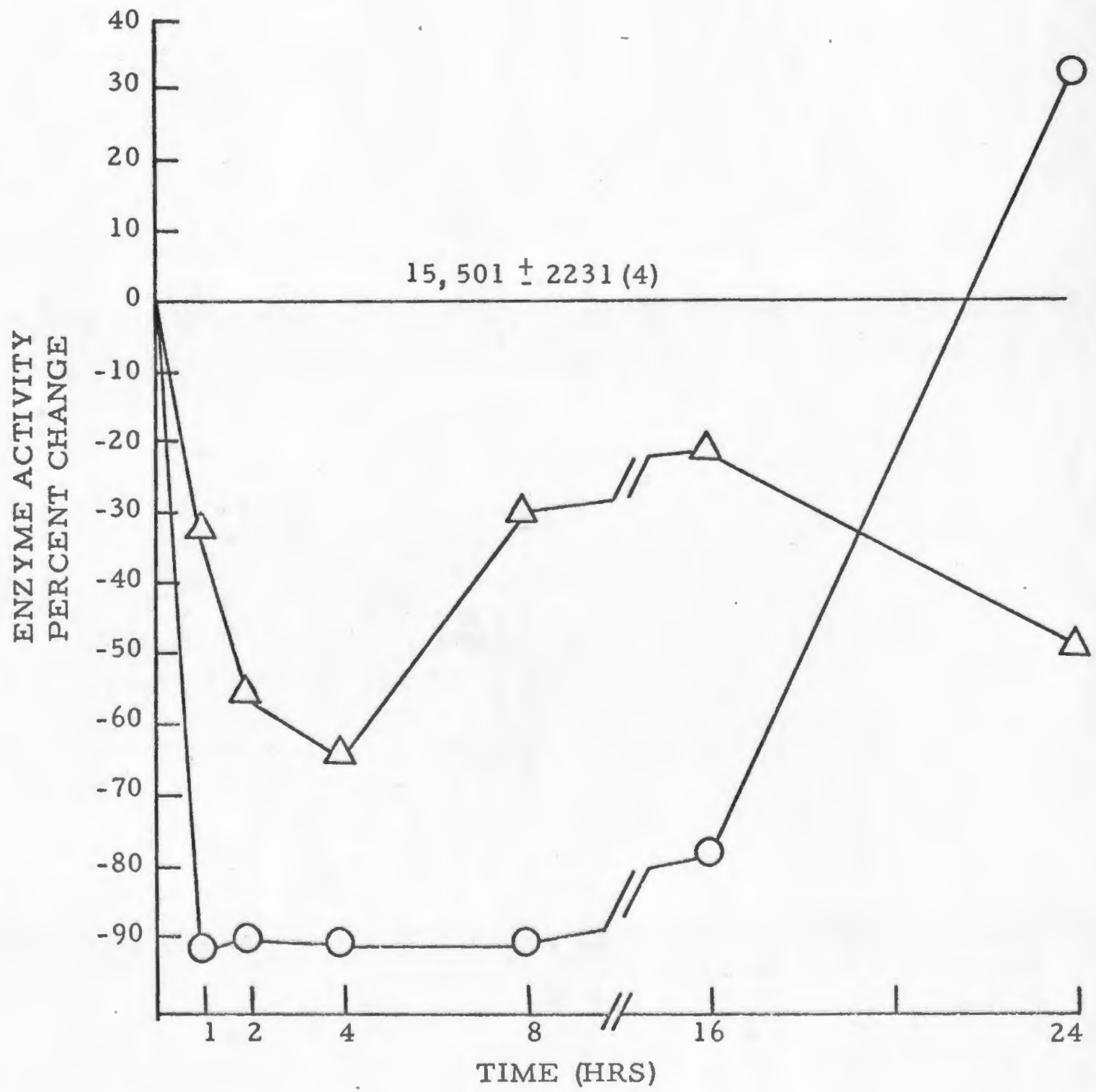

Figure 3: Alteration of histone acetylation by estradiol and phenylglyoxal. Each point represents the mean of at least three values, each obtained from the pooled tissue of two animals. Enzyme activity of control animals is expressed as $\mathrm{Dpm} / \mathrm{mg}$ protein $/ 30 \mathrm{~min}$. (O-O) estradiol, $10 \mu \mathrm{g} / \mathrm{rat}$, i. p. ; $(\Delta \triangle$ ) phenylglyoxal, $250 \mathrm{mg} / \mathrm{kg}$, i. p. 
Enzyme activity response to phenylglyoxal administration closely followed the response seen with estradiol. Uterine enzyme activity decreased rapidly, although not as markedly as noted following estradiol treatment. Reversal of the phenylglyoxal mediated depress ion in enzyme activity began 4 to 8 hours following drug administration. However, enzyme activity had not returned to control levels 24 hours after phenylglyoxal. A significant $(P<0.05)$ elevation in uterine wet weight was seen two hours after estradiol administration. The initial, rapid elevation was followed by a second but less dramatic one which began at about 6 hours after hormone treatment. At 24 hours, uterine wet weight was elevated to approximately 180 percent of control. Uterine wet weight of phenylglyoxal treated animals did not change significantly $(P>0.05)$ from control values when the parameter was measured over the 24 hour period following drug administration (Figure 4).

Having determined the time course of estradiol and phenylglyoxal activity, it was of interest to determine whethe $r$ the glyoxals, methylglyoxal and phenylglyoxal, were capable of altering the elevation in uterine histone acetylation and wet weight which had been observed 24 hoursfollowing estradiol treatment. At 20 hours following either estradiol vehicle or hormone treatment, (estradiol, $10 \mu g / \mathrm{rat}$, intraperitoneally) groups of animals received either methylglyoxal, phenylglyoxal or a phosphate buffer vehicle. All animals were 


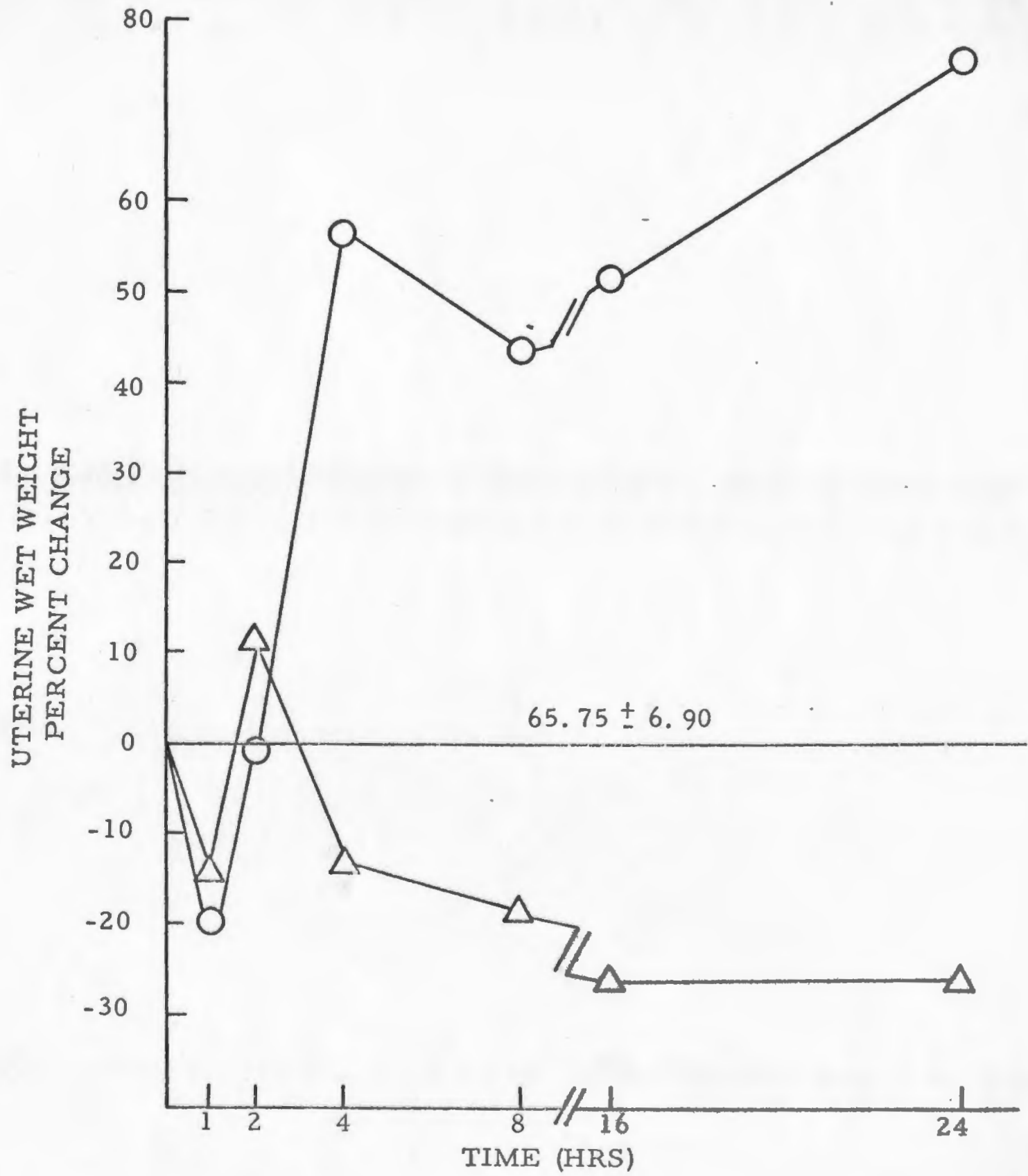

Figure 4: Alteration of uterine wet weight by estradiol and phenylglyoxal. Each point represents the mean of at least six values. Uterine weight of control animals is expressed as $\mathrm{mg}$ wet weight. (O-O) estradiol, $10 \mu \mathrm{g} / \mathrm{rat}, \mathrm{i}$. p. ; $(\Delta-\Delta)$ ) phenylglyoxal, $250 \mathrm{mg} / \mathrm{kg}$, i.p. 
sacrificed 24 hours following estradiol treatment. Data presented in Table 6 indicate that estradiol $-17-\beta$ administration causes a rapid increase above controls in ute rine wet weight $(P<0.0025), 24$ hours following hormone administration. Uterine wet weight did not change significantly (P $>0.05)$ from control level when measured 4 hours following methylglyoxal administration at either of the doses used in this study. Weight of uterine tis sue obtained from animals treated with estradiol and subsequently with methylglyoxal was elevated above that for vehicle treated controls. Similar results were obtained with phenylglyoxal (Table 7).

The effect of hormone treatment alone and in combination with either methylglyoxal or phenylglyoxal at two dose levels is shown in Tables 6 and 7 respectively. When measured in vitro following 24 hour estradiol treatment, enzyme activity was significantly $(P<0.0005)$ elevated above control values. Elevation of ute rine enzyme activity 24 hours following estradiol was more pronounced in this study than the increase reported in the estradiol time course study. Variation in both the age of the animals ( 25 day old versus 30 day old rats) and changes in the brand and preparation of the estradiol solution may account for the observed differences.

Methylglyoxal at both dose levels depressed enzyme activity when this parameter was measured 4 hours after glyoxal administration 
Table 6. Effect of methylglyoxal treatment on uterine weight and histone acetylation in untreated and estradiol pretreated rats

\begin{tabular}{|c|c|c|}
\hline Treatment ${ }^{\mathrm{a}}$ & $\begin{array}{l}\text { Uterine Wet Weight (mg) } \\
\text { Mean } \pm \text { S.E. (N) }\end{array}$ & $\begin{array}{l}\text { Enzyme Activity }{ }^{\mathrm{b}} \\
\mathrm{dpm} / \mathrm{mg} \text { Protein } / 30 \mathrm{~min} \\
\text { Mean IS.E. (N) }\end{array}$ \\
\hline Control & $104 \pm 12(6)$ & $12,582 \pm 1071(6)$ \\
\hline Estradiol-17- $\beta$ & $\begin{array}{l}178 \pm 11(8) \\
(P<.0025)^{* *}\end{array}$ & $\begin{array}{l}26,209 \pm 3056(8) \\
(P<.0005)^{*}\end{array}$ \\
\hline $\begin{array}{l}\text { Me thylglyoxal } \\
125 \mathrm{mg} / \mathrm{kg} \text {, i. p. }\end{array}$ & $\begin{array}{l}98 \pm 11(7) \\
(\mathrm{P}>.05)^{*}\end{array}$ & $\begin{array}{l}8,033 \pm 1291(7) \\
(P<.025)^{*}\end{array}$ \\
\hline $\begin{array}{l}\text { Methylglyoxal } \\
250 \mathrm{mg} / \mathrm{kg} \text {, i. p. }\end{array}$ & $\begin{array}{l}104 \pm 11(7) \\
(P>.05)^{*}\end{array}$ & $\begin{array}{l}8,947 \pm 877(7) \\
(P<.025) *\end{array}$ \\
\hline $\begin{array}{l}\text { Estradiol plus } \\
\text { Methylglyoxal } \\
125 \mathrm{mg} / \mathrm{kg} \text {, i.p. }\end{array}$ & $\begin{array}{l}149 \pm 11(7) \\
(P<.01)^{*}\end{array}$ & $\begin{array}{l}5,022 \pm 693(7) \\
(P<.0005)^{*}\end{array}$ \\
\hline $\begin{array}{l}\text { Estradiol plus } \\
\text { Methylglyoxal } \\
250 \mathrm{mg} / \mathrm{kg} \text {, i. p. }\end{array}$ & $\begin{array}{l}172 \pm 9(8) \\
(P<.0005)^{*}\end{array}$ & $\begin{array}{l}6,666 \pm 717(8) \\
(P<.0005) *\end{array}$ \\
\hline
\end{tabular}

a

Control: $0.2 \mathrm{ml}$ estradiol vehicle followed by $1 \mathrm{ml} / \mathrm{kg} 0.05 \mathrm{M}$ phos phate buffer (vehicle), i.p. $20 \mathrm{hrs}$ after; Estradiol: $0.2 \mathrm{ml}$ $(10 \mu \mathrm{g}) / \mathrm{rat}$, i.p; Methylglyoxal: $125 \mathrm{mg} / \mathrm{kg}$, i. p. (or $250 \mathrm{mg} / \mathrm{kg}$, i. p.) administered $20 \mathrm{hrs}$ following estradiol vehicle: Estradiol plus Methylglyoxal: estradiol, $10 \mu \mathrm{g} / \mathrm{rat}$, i. p. followed by methylglyoxal $125 \mathrm{mg} / \mathrm{kg}$, i. p. (or $250 \mathrm{mg} / \mathrm{kg}$, i. p.) $20 \mathrm{hrs}$ after estradiol adminis tration. All animals were sacrificed $24 \mathrm{hrs}$ following estradiol administration ( 4 hrs following methylglyoxal administration).

${ }^{b}$ Enzyme activity is expressed as the Mean \pm S. E. of the amount (dpm) of ${ }^{14} \mathrm{C}$-acetate incorporated histone formed per $\mathrm{mg}$ uterine protein $(10,000 \times \mathrm{g}$ supernatant) per $30 \mathrm{~min}$.

$*$

Determined by Student "t" test. 
Table 7. Effect of phenylglyoxal treatment on uterine weight and histone acetylation in untreated and estradiol pretreated rats

\begin{tabular}{|c|c|c|}
\hline Treatment ${ }^{a}$ & $\begin{array}{l}\text { Uterine Wet Weight (mg) } \\
\text { Mean } \pm \text { S.E. (N) }\end{array}$ & $\begin{array}{c}\text { Enzyme Activity } \\
\mathrm{dpm} / \mathrm{mg} \text { Protein } / 30 \mathrm{~min} \\
\text { Mean } \mathrm{S} \text {. E. (N) }\end{array}$ \\
\hline Control & $104 \pm 12(6)$ & $12,582 \pm 1071(6)$ \\
\hline Estradiol-17- $\beta$ & $\begin{array}{l}178 \pm 11(8) \\
(P<.0025)^{*}\end{array}$ & $\begin{array}{l}26,209 \pm 3056(8) \\
(\mathrm{P}<.0005)^{*}\end{array}$ \\
\hline $\begin{array}{l}\text { Phenylglyoxal } \\
125 \mathrm{mg} / \mathrm{kg} \text {, i.p. }\end{array}$ & $\begin{array}{l}116 \pm 8(10) \\
(P>.05)^{*}\end{array}$ & $\begin{array}{l}8,215 \pm 1153(10) \\
(\mathrm{P}<.0125)^{*}\end{array}$ \\
\hline $\begin{array}{l}\text { Phenylglyoxal } \\
250 \mathrm{mg} / \mathrm{kg} \text {, i. p. }\end{array}$ & $\begin{array}{l}109 \pm 15(6) \\
(P>.05)^{*}\end{array}$ & $\begin{array}{l}7,123 \pm 1016(6) \\
(P<.01) *\end{array}$ \\
\hline $\begin{array}{l}\text { Estradiol plus } \\
\text { Phenylglyoxal } \\
250 \mathrm{mg} / \mathrm{kg} \text {, i. p. }\end{array}$ & $\begin{array}{l}177 \pm 13(10) \\
(P<.0025)^{*}\end{array}$ & $\begin{array}{l}7,638 \pm 796(10) \\
(P<.0025)^{*}\end{array}$ \\
\hline
\end{tabular}

a

Control: $0.2 \mathrm{ml}$ estradiol vehicle followed by $1 \mathrm{ml} / \mathrm{kg} 0.05 \mathrm{M}$ phos phate buffer (vehicle), i.p. $20 \mathrm{hrs}$ after; Estradiol: $0.2 \mathrm{ml}$

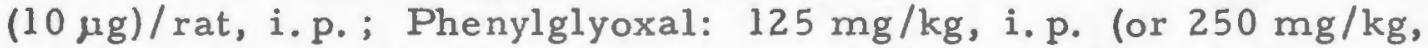
i. p. ) administered $20 \mathrm{hrs}$ following estradiol vehicle; Estradiol plus Phenylglyoxal: estradiol, $10 \mu \mathrm{g} / \mathrm{rat}$, i. p. followed by phenylglyoxal $250 \mathrm{mg} / \mathrm{kg}$, i. p., $20 \mathrm{hrs}$ after estradiol administration. All animals were sacrificed 24 hrs following estradiol administration (4 hrs following phenylglyoxal administration).

${ }^{b}$ Enzyme activity is expressed as the Mean $t S . E$. of the amount (dpm) of ${ }^{14} \mathrm{C}$-acetate incorporated histone formed per mg uterine protein $(10,000 \times \mathrm{g}$ supernatant) per $30 \mathrm{~min}$.

*

Determined by Student " $t$ " test. 
(Table 6). Similarly, phenylglyoxal treated groups showed lower uterine enzyme activity when measured at the 4 hour interval (Table 7). The glyoxal mediated depression in enzyme activity was also apparent in animals who had received estradiol 20 hours prior to either methylglyoxal or phenylglyoxal (Tables 6 and 7). Elevations in ute rine histone acetylation seen 24 hours following estradiol alone were not seen in animals réceiving estradiol followed by either glyoxal. Drug induced alterations in uterine histone acetylation are presented in Figure 5 and 6.

A dose response comparison of the effects of the glyoxals on enzyme activity and uterine wet weight is given in Table 8. The depression of histone acetylation by methylglyoxal and phenylglyoxal administered at $125 \mathrm{mg} / \mathrm{kg}$ was not significantly different from results obtained at the $250 \mathrm{mg} / \mathrm{kg}$ dose level. Similarly, there was no difference between dose levels of either drug on uterine weight of glyoxal treated animals.

The data presented in Table 9 indicate that methylglyoxal and phenylglyoxal administered to animals pretreated with estradiol for 20 hours significantly altered the estradiol mediated elevation of uterine histone acetylation activity seen at 24 hours in animals receiving estradiol alone. Neither methylglyoxal nor phenylglyoxal significantly altered the estradiol mediated increase in utcrine weight. 


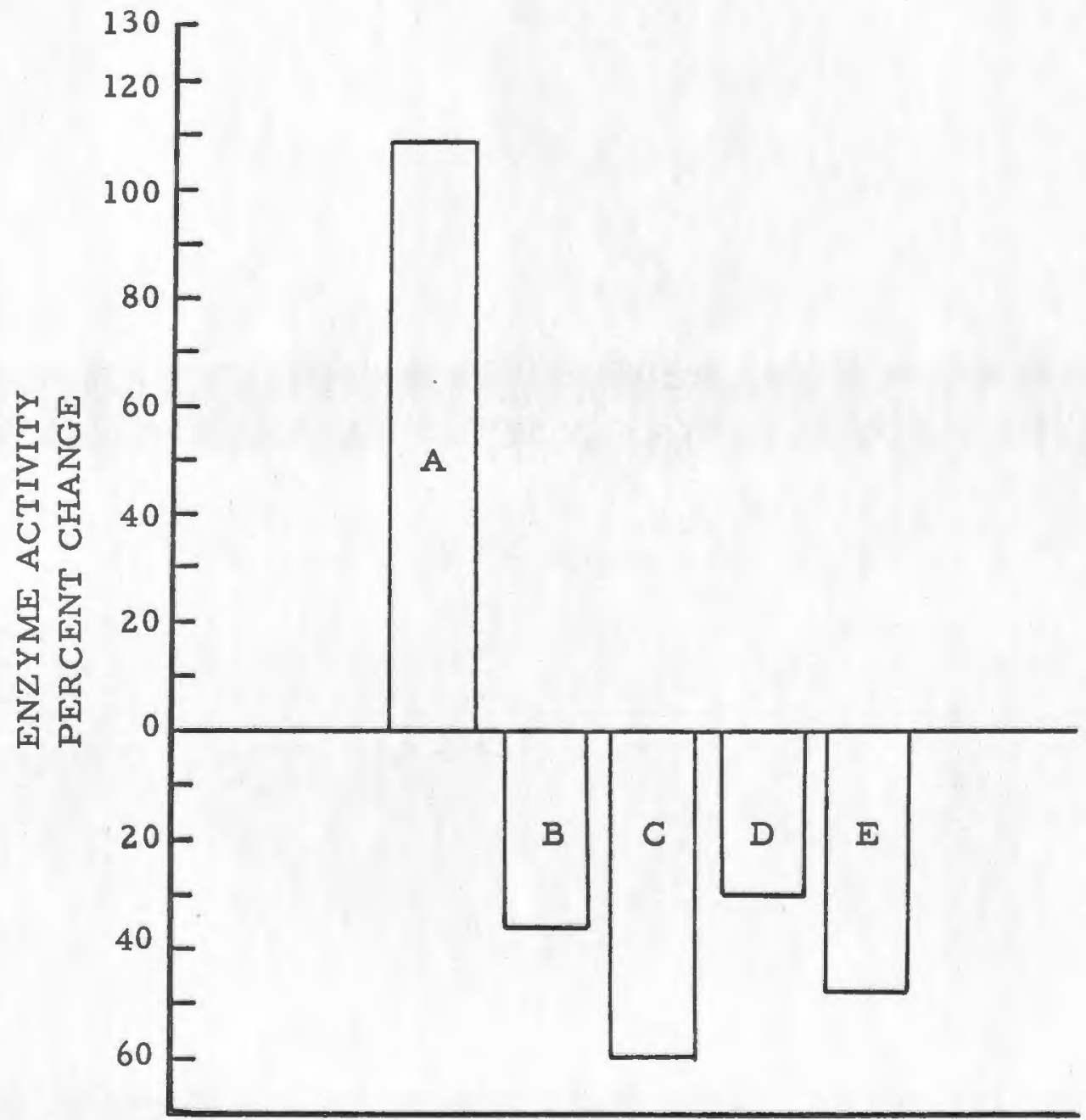

Figure 5: Alteration of histone acetylation in rat uterus by estradiol and methylglyoxal, expressed as percent change from control. Bars represent mean of at least six animals. Drug treated animals received either estradiol and methylglyoxal alone or methylglyoxal 20 hr. post estradiol. All animals we re sacrificed 24 hrs. following estradiol administration. (A) estradiol; $10 \mathrm{\mu g} / \mathrm{rat}$, i. p. ; (B) methylglyoxal, $125 \mathrm{mg} / \mathrm{kg}$, i. p. ; (C) estradiol plus methylglyoxal, $125 \mathrm{mg} / \mathrm{kg}$; (D) methyglyoxal, $250 \mathrm{mg} / \mathrm{kg}$; (E) estradiol plus methylglyoxal, $250 \mathrm{mg} / \mathrm{kg}$. 


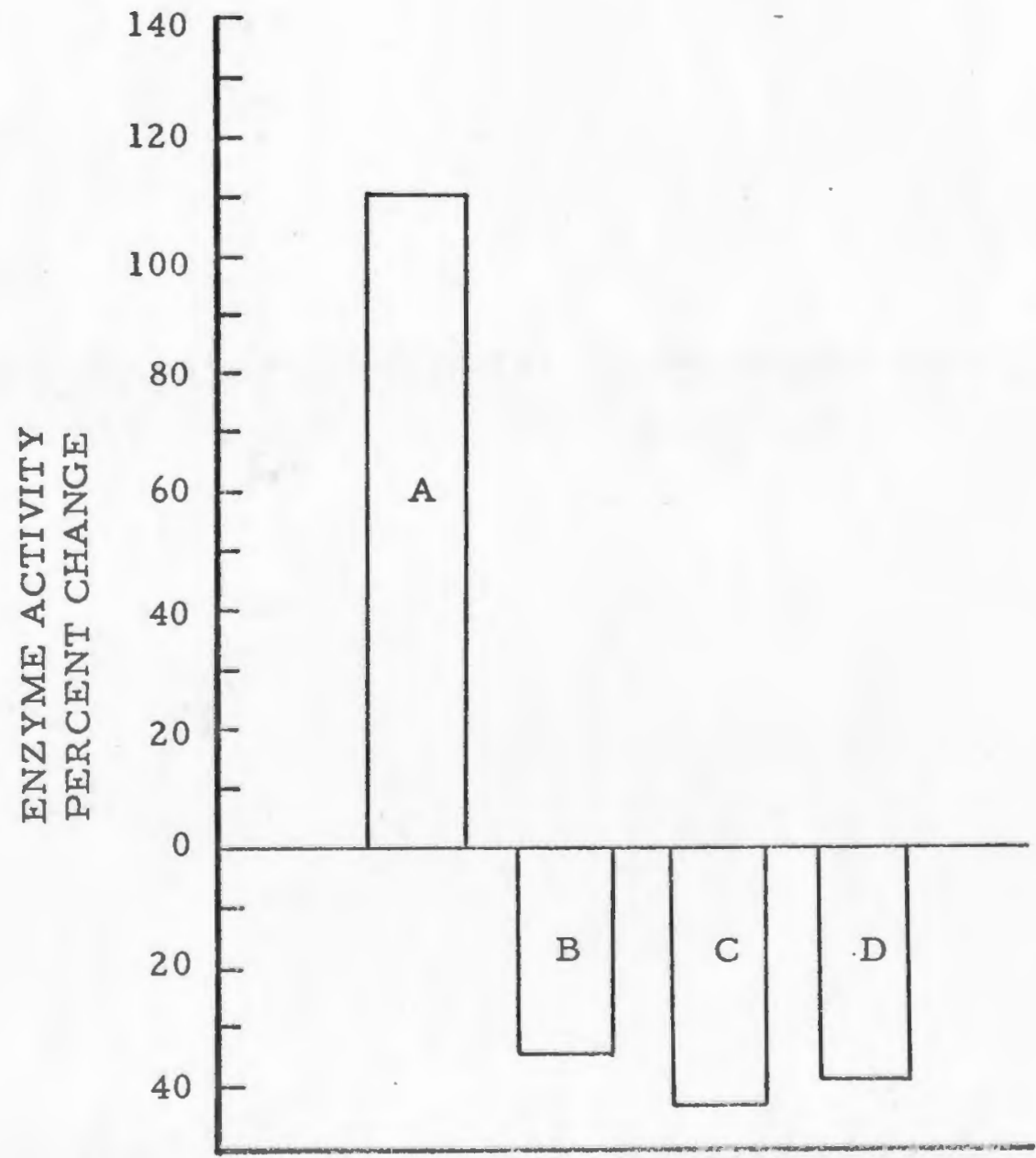

Figure 6: Alteration of histone acetylation in rat uterus by estradiol and phenylglyoxal, expressed as percent change from control. Bars represent the mean of at least six animals. Drug treated animals received either estradiol and phenylglyoxal alone or phenylglyoxal $20 \mathrm{hrs}$. post estradiol. All animals were sacrificed 24 hrs. following estradiol administration. (A) estradiol, $10 \mu \mathrm{g} / \mathrm{rat}$, i.p.; (B) phenylglyoxal, $125 \mathrm{mg} / \mathrm{kg}$, i.p. ; (C) phenylglyoxal, $250 \mathrm{mg} / \mathrm{kg}$, i. p.; (D) estradiol plus phenylglyoxal, $250 \mathrm{mg} / \mathrm{kg}$. 
Table 8. Comparison of alterations in ute rine histone acetylation and uterine wet weight at two dose levels of methylglyoxal and phenylglyoxal

\begin{tabular}{lcc}
\hline Treatment & $\begin{array}{c}\text { Enzyme Activity } \\
\text { Ute rine Wet Weight }(\mathrm{mg}) \\
\text { Mean }\end{array}$ & $\begin{array}{c}\text { S.E. (N) } \\
\text { dpmg Protein } / 30 \mathrm{~min} \\
\text { Mean } \pm \text { S. E. (N) }\end{array}$ \\
\hline Methylglyoxal & $98 \pm 11$ & \\
\hline $125 \mathrm{mg} / \mathrm{kg}$ & $104 \pm 11$ & $8,033 \pm 1291(7)$ \\
$250 \mathrm{mg} / \mathrm{kg}$ & $(\mathrm{P}>.05)^{*}$ & $8,947 \pm 871(7)$ \\
Phenylglyoxal & $116 \pm 8$ & $(\mathrm{P}>.05)^{*}$ \\
$125 \mathrm{mg} / \mathrm{kg}$ & $109 \pm 15$ & $8,215 \pm 1153(10)$ \\
$250 \mathrm{mg} / \mathrm{kg}$ & $(\mathrm{P}) .05)^{*}$ & $7,123 \pm 1016(6)$ \\
& & $(\mathrm{P}>.05)^{*}$ \\
\hline
\end{tabular}

${ }^{2}$ The glyoxals were administered, i.p. $4 \mathrm{hrs}$ prior to sacrifice.

b

Enzyme activity is expressed as the Mean IS. E. of the amount (dpm) of ${ }^{14} \mathrm{C}$-acetate incorporated histone formed per mg uterine protein $(10,000 \times \mathrm{g}$ supernatant) per $30 \mathrm{~min}$.

*Determined by Student " $t$ " test. 
Table 9. Effect of methylglyoxal and phenylglyoxal treatment on the estradiol mediated stimulation of histone acetylation and uterine weight.

\begin{tabular}{|c|c|c|}
\hline Treatment ${ }^{a}$ & $\begin{array}{l}\text { Uterine Wet Weight (mg) } \\
\text { Mean IS.E. (N) }\end{array}$ & $\begin{array}{l}\text { Enzyme Activity } \\
\text { dpm/mg Protein } / 30 \mathrm{~min} \\
\text { Mean } \pm \text { S.E. (N) }\end{array}$ \\
\hline Estradiol-17- $\beta$ & $178 \pm 11$ & $26,209 \pm 3056(8)$ \\
\hline $\begin{array}{l}\text { Estradiol plus } \\
\text { Methylglyoxal } \\
125 \mathrm{mg} / \mathrm{kg} \text {, i. P. }\end{array}$ & $\begin{array}{l}149 \pm 11 \\
(P>.05)^{*}\end{array}$ & $\begin{array}{l}5,022 \pm 639(7) \\
(P<.0005)^{*}\end{array}$ \\
\hline $\begin{array}{l}\text { Estradiol plus } \\
\text { Methylglyoxal } \\
250 \mathrm{mg} / \mathrm{kg} \text {, i.p. }\end{array}$ & $\begin{array}{l}172 \pm 9 \\
(P>.05)^{*}\end{array}$ & $\begin{array}{l}6,666 \pm 717(8) \\
(P<.0005)^{*}\end{array}$ \\
\hline $\begin{array}{l}\text { Estradiol plus } \\
\text { Phenylglyoxal } \\
250 \mathrm{mg} / \mathrm{kg} \text {, i. p. }\end{array}$ & $\begin{array}{l}177 \pm 13 \\
(P>.05)^{*}\end{array}$ & $\begin{array}{l}7,638 \pm 791(10) \\
(P<.0005)^{*}\end{array}$ \\
\hline
\end{tabular}

Estradiol: $0.2 \mathrm{ml}(10 \mu \mathrm{g}) / \mathrm{rat}$, i.p. ; Estradiol plus Methylglyoxal: estradiol, $10 \mathrm{\mu g} / \mathrm{rat}$, i.p. followed by methylglyoxal, $125 \mathrm{mg} / \mathrm{kg}$, i. p. (or $250 \mathrm{mg} / \mathrm{kg}$, i.p.) $20 \mathrm{hrs}$ after estradiol administration; Estradiol plus Phenylglyoxal: estradiol, $10 \mu \mathrm{g} / \mathrm{rat}$, i.p., followed by phenylglyoxal, $250 \mathrm{mg} / \mathrm{kg}$, i.p. $20 \mathrm{hrs}$ after estradiol. All animals were sacrificed $24 \mathrm{hrs}$ following estradiol administration ( $4 \mathrm{hrs}$ following administration of either glyoxal).

${ }^{b}$ Enzyme activity is expressed as the Mean $\pm S . E$. of the amount (dpm) of ${ }^{14} \mathrm{C}$-acetate incorporated histone formed per $\mathrm{mg}$ uterine protein $(10,000 \times \mathrm{g}$ supernatant) per $30 \mathrm{~min}$.

*

Determined by Student " $t$ " test. 
Table 10 shows the effect of phenylglyoxal, $125 \mathrm{mg} / \mathrm{kg}$, administered 4 hours prior to sacrifice, on uterine weight total DNA, RNA/DNA ratio and protein/DNA ratio. DNA was employed as a baseline in this and parallel studies because, unlike uterine RNA and protein, its concentration remains relatively constant during growth changes and alterations in hormonal environment. When compared to vehicle treated controls, uterine tissue obtained from animals treated for 4 hours with phenylglyoxal did not differ significantly in the various parameters monitored in this study.

Uterine wet weight, total DNA, RNA and protein were measured, and the uterine/body, RNA/DNA and protein/DNA ratios were determined in animals.treated with phenylglyoxal alone and in combinations with estradiol. In this study, animals received phenylglyoxal, 125 $\mathrm{mg} / \mathrm{kg}$, intraperitoneally, daily for two days. A single injection of estradiol, $10 \mu \mathrm{g} / \mathrm{rat}$, intraperitoneally, was administered to $\mathrm{r}$ ats which had received only phosphate buffer vehicle for two days. A second group of rats which had received phenylglyoxal for two days also received a single injection of estradiol. All groups were sacrificed 24 hours following estradiol treatment and subsequent determinations were performed on the excised uterine tissue. The data presented in Table 11 indicate that estradiol given alone elevated uterine wet weight, whereas phenylglyoxal administered for 2 days did not significantly alter this parameter. The uterine weight of 
Table 10. Effect of 4 hour phenylglyoxal treatment on wet weight and nucleic acid content in the immature rat uterus

\begin{tabular}{|c|c|c|c|c|c|}
\hline Treatment & $\begin{array}{c}\text { Uterine Wet } \\
\text { Weight (mg) } \\
\text { Mean } \pm \text { S.E. (N) }\end{array}$ & $\begin{array}{c}\text { Uterine / Body } \\
\text { Ratio }(\%) \\
\text { Mean } \pm \text { S. E. (N) }\end{array}$ & $\begin{array}{l}\frac{\text { Total DNA }}{\text { Pooled Uteri (mg) }} \\
\text { Mean } \pm \text { S.E. (N) }\end{array}$ & $\begin{array}{c}\frac{\text { RNA }}{\text { DNA }} \\
\text { Mean } \pm \text { S.E }(\mathrm{N})\end{array}$ & $\begin{array}{c}\frac{\text { Protein }}{\text { DNA }} \\
\text { Mean IS.E.(N) }\end{array}$ \\
\hline Control $^{a}$ & $53 \pm 5(12)$ & $0.079 \pm .005(12)$ & $.94 \pm .07(5)$ & .508 & 10.7 \\
\hline Phenylglyoxal ${ }^{b}$ & $\begin{array}{l}54 \pm 4(12) \\
(P>.05)^{*}\end{array}$ & $\begin{array}{c}0.082 \pm .006(12) \\
(P>.05)^{*}\end{array}$ & $\begin{array}{c}.83 \pm .07(5) \\
(P>.05)^{*}\end{array}$ & $\left.(P\rangle^{.497} .05\right)^{*}$ & $(P>.05)^{*}$ \\
\hline
\end{tabular}

${ }^{a}$ Control: vehicle, $1 \mathrm{ml} / \mathrm{kg}$, i. p. of $0.05 \mathrm{M}$ phosphate buffer $(\mathrm{pH} 7.4)$ administered 4 hours prior to sacrifice.

${ }^{b}$ Phenylglyoxal: dissolved in vehicle and administered 4 hours prior to sacrifice, $125 \mathrm{mg} / \mathrm{kg}, \mathrm{i} . \mathrm{p}$.

* Determined by Student " $t$ " test. 
Table 11. Effect of 48 hour phenylglyoxal pretreatment on estradiol. mediated alterations in immature rat uterus

\begin{tabular}{lcc}
\hline Treatment & $\begin{array}{c}\text { Uterine Wet Weight (mg) } \\
\text { Mean } \pm \text { S.E. (N) }\end{array}$ & $\begin{array}{c}\text { Uterus/Body Ratio (\%) } \\
\text { Mean } \pm \text { S.E. (N) }\end{array}$ \\
\hline Control & $62 \pm 12(12)$ & $.082 \pm .009(12)$ \\
Estradiol & $182 \pm 12(12)$ & $\begin{array}{c}27 \pm .002(12) \\
(P<.001)^{*}\end{array}$ \\
Phenylglyoxal & $(\mathrm{P}<.001)^{*}$ & $17 \pm .01(10)$ \\
Plus estradiol & $98 \pm 7(10)$ & $(P<.001)^{*}$ \\
Phenylglyoxal & $(P<.005)^{*}$ & $.092 \pm .004(10)$ \\
& $51 \pm 4(10)$ & $(P>.05)^{*}$ \\
\hline
\end{tabular}

a

Control: vehicle, $1 \mathrm{ml} / \mathrm{kg}$, i.p. of $0.05 \mathrm{M}$ phosphate buffer (pH 7.4) administered once daily for 2 days; Estradiol-17- $\beta$; $10 \mu \mathrm{g} / \mathrm{rat}$, i.p. administered $24 \mathrm{hrs}$ prior to sacrifice; Phenylglyoxal plus Estradiol: $125 \mathrm{mg} / \mathrm{kg}$, i. p. administered daily for 2 days, plus estradiol, $10 \mu \mathrm{g} / \mathrm{rat}$, single injection on day 2 of treatment. Animals were sacrificed $24 \mathrm{hrs}$ following estradiol; Phenylglyoxal: $125 \mathrm{mg} / \mathrm{kg}$, i.p. administered daily for 2 days. Animals were sacrificed $24 \mathrm{hrs}$ following last injection

*Determined by Student " $t$ " test. 
animals pretreated with phenylglyoxal for two days, and then given estradiol was significantly elevated above vehicle treated controls. These alterations were also reflected in the uterine/body weight ratio. As noted in Table 12, total DNA, RNA/DNA ratio, and protein/DNA ratio were significantly elevated in uterine tissue obtained from estradiol treated animals. Measurement of the se parameters in uterine tissue of phenylglyoxal treated animals indicate that total DNA was not altered, whereas both the RNA/DNA ratio and protein/DNA ratio were significantly $(P<0.005)$ decreased as compared to vehicle treated controls. The uteri of animals pretreated with phenylglyoxal and then given estradiol contained the same total amount of DNA as was found in vehicle treated controls. However, both the RNA/DNA and protein/DNA ratios were elevated above control values. In Table 13 a comparison is made between the effects of estradiol on the immature rat uterus and the action of the hormone when given to animals who had received phenylglyoxal for 2 days prior to estradiol administration. Uterine wet weight in phenylglyoxal pretreated animals was approximately 50 percent that of estradiol treated animals. Total uterine DNA and the protein/DNA ratio were significantly $(P<0.05)$ decreased when compared to the estradiol treated group. The uterine RNA/DNA ratio of estradiol treated animals did not differ from values obtained from the uterus of phenylglyoxal pretreated animals receiving the hormone. 
Table 12. Effect of 48 hour phenylglyoxal pretreatment on estradiolmediated alterations in immature rat uterus

\begin{tabular}{|c|c|c|c|}
\hline Treatment ${ }^{2}$ & $\begin{array}{c}\frac{\text { DNA.(mg) }}{\text { Pooled Uteri }} \\
\text { Mean E S.E. (N) }\end{array}$ & $\begin{array}{c}\text { RNA/DNA } \\
\text { Mean I S.E. (N) }\end{array}$ & $\begin{array}{c}\text { Protein/DNA } \\
\text { Mean IS.E. (N) }\end{array}$ \\
\hline Control & $0.86 \pm .06(5)$ & $0.600 \pm .016(5)$ & $11.21 \pm 0.65(5)$ \\
\hline Estradiol & $\begin{array}{c}1.21 \pm .09(6) \\
(P<.02)^{*}\end{array}$ & $\begin{array}{c}0.82 .5 \pm .039(6) \\
(P<.001)^{*}\end{array}$ & $\begin{array}{c}18.30 \pm 1.18(6) \\
(P<.001) *\end{array}$ \\
\hline $\begin{array}{l}\text { Phenylglyoxal } \\
\text { plus estradiol }\end{array}$ & $\begin{array}{l}0.83 \pm .12(5) \\
(P>.05)^{*}\end{array}$ & $\begin{array}{l}0.831 \pm .020 *(5) \\
(P<.001) *\end{array}$ & $\begin{array}{c}13.00 \pm 0.31(5) \\
(P<.05)^{*}\end{array}$ \\
\hline Phenylglyoxal & $\begin{array}{c}0.77 \pm .06(5) \\
(P>.05)^{*}\end{array}$ & $\begin{array}{c}0.490 \pm .020(5) \\
(P<.005)^{*}\end{array}$ & $\begin{array}{l}7.78 \pm 0.30(5) \\
(P<.005)^{* *}\end{array}$ \\
\hline
\end{tabular}

Control: vehicle, $1 \mathrm{mg} / \mathrm{kg}$, i.p of $0.05 \mathrm{M}$ phosphate buffer ( $\mathrm{pH} 7.4$ ) administered once daily for 2 days; Estradiol-17 - ; $10 \mathrm{ug} / \mathrm{rat}$, i. p. administered $24 \mathrm{hrs}$ prior to sacrifice; Phenylglyoxal plus Estradiol: phenylglyoxal, $125 \mathrm{mg} / \mathrm{kg}$, i.p. administered daily for 2 days, plus estradiol, $10 \mathrm{ug} / \mathrm{rat}$, single injection on day 2 of treatment.

Animals were sacrificed $24 \mathrm{hrs}$ following estradiol; Phenylglyoxal: $125 \mathrm{mg} / \mathrm{kg}$, i. p. administered once daily for 2 days. Animals were sacrificed 24 hrs following last injection.

${ }^{b}$ Represents Mean S.E. of total DNA content of samples containing two pooled uteri.

*

Determined by Student " $t$ " test. 
Table 13. Effect of 48 hour phenylglyoxal pretreatment on estradiol-mediated alterations in the immature rat uterus: Comparison between hormone treatment alone and in combination with phenylglyoxal.

\begin{tabular}{|c|c|c|c|c|}
\hline Treatment ${ }^{a}$ & $\begin{array}{c}\text { Uterine Wet } \\
\text { Weight (mg) } \\
\text { Mean } \pm \text { S.E. (N) }\end{array}$ & $\begin{array}{l}\frac{\text { DNA }^{b}}{\text { Pooled Uteri }} \\
\text { Mean ES.E. (N) }\end{array}$ & $\begin{array}{c}\frac{\text { RNA }}{\mathrm{DNA}} \\
\text { Mean } \pm S . E .(\mathrm{N})\end{array}$ & $\begin{array}{c}\frac{\text { Protein }}{\text { DNA }} \\
\text { Mean } \pm \text { S.E. (N) }\end{array}$ \\
\hline Estradiol & $182 \pm 12(12)$ & $1.2 \pm .09(6)$ & $.825 \pm .039$ & $18.3 \pm 1.2$ \\
\hline $\begin{array}{l}\text { Estradiol plus } \\
\text { Phenylglyoxal }\end{array}$ & $\begin{array}{l}98 \pm 7(10) \\
(P<.001)^{*}\end{array}$ & $\begin{array}{l}.83 \pm .12(5) \\
\left(P(.05)^{*}\right.\end{array}$ & $\begin{array}{l}.831 \pm .02 \\
(P) .05)^{*}\end{array}$ & $\begin{array}{l}13.0 \pm .31 \\
(P<.005)^{*}\end{array}$ \\
\hline
\end{tabular}

${ }^{2}$ Estradiol-17- $\beta$ : $10 \mathrm{ug} / \mathrm{rat}$, i.p. administered $24 \mathrm{hrs}$ prior to sacrifice; Phenylglyoxal: $125 \mathrm{mg} / \mathrm{kg}$, i. p. administered daily for 2 days plus estradiol, $10 \mu \mathrm{g} / \mathrm{rat}, \mathrm{i} . \mathrm{p}$., single injection on day 2 of treatment. All animals were sacrificed $24 \mathrm{hrs}$ following estradiol.

${ }^{b}$ Represents Mean $\pm S . E$. of total DNA content of samples containing two pooled uteri.

*Determined by Student " $t$ " test. 


\section{DISCUSSION}

The in vitro studies of the effect of various ketoaldehydes on uterine histone acetylation suggest a dose dependent inhibitory action (Figure 1). The nature of the $I_{50}$ study (Table 1) makes it difficult to relate the values for glyoxal concentrations obtained in this study to those found to be effective in other laboratories. The $\mathrm{I}_{50}$ value is dependent upon the protein content used in the system being analyzed, in this case, both enzymatic and other cell protein; therefore, the $I_{50}$ values reported in our stucly will not necessarily correlate with similar studies that used a different protein content in their assay system. It is of interest to note, however, that the various glyoxal derivatives employed in several reported studies (Gregg, 1968; Klamerti, 196́8; Szent-Gyorgyi, 1968) were active at concenimations similar to the $I_{50}$ values reported in our studies. Scaife (1969), using $\mathrm{mM}$ concentrations, obtained methylylyoxal and kethoxal mediated in viluo inhibition of human kidney cell DNA, RNA, and protein syrihesis. Similar concentrations of glyoxal (0.5nM) are capabie of bjocking DNA. replication and protein synthesis without affecting respiration in human fibroblast coll cultures (Itamerth, 1968). In adcition, a sharp concentration effect, evident in the dose response study was reported to occur with methylglyoxal when the drug was tested for mitotic inhibitory properties (Scaife, 1969). While a direct correlation between these 
literature reports and the present study is not warranted, it is noteworthy that several studies involving different biological systems show that glyoxal derivatives are effective at similar concentrations.

Although inhibition of in vitro histone acetylation had been demonstrated by our previous studies, the mechanism(s) involved in these actions was left undetermined. Results obtained from the study of glyoxal mediated inhibition at the incubation level (Tables 2, 3) suggest that the major site of action is the uterine acetylation enzyme system. However, a direct alteration of histone protein leading to a blockade of acetylation must also be considered, since phenylglyoxalhistone preincubation results in a significant decrease in the in vitro acetylation of histone protein. Takahashi (1968) demonstrated a blockade of guanido residues in protein, which may account in part for the decrease in histone acetylation following incubation of histone protein in the presence of phenylglyoxal.

The results of our in vitro studies led to an analysis of the in vivo effects of the glyoxal derivatives. According to present concepts of histone function(s), blockade of histone acetylation in vivo might be expected to alter normal growth patterns in a biological system. The rat uterus, which had been employed during our preliminary studies, was chosen as a model system in which to study glyoxal action, because of the well defined growth pattern initiated by hormonal stimulation. Although an alteration in uterine histone acetylation 
following estradiol treatment had not been reported in the lite rature prior to the initiation of these studies, it was our belief that hormone treatment would affect this parameter and that hormone-induced alterations in the target organ could be blocked to some extent by the glyoxals. Results obtained from our initial in vivo studies indicated that the two glyoxals, Methyl-GAG and glyoxal monohydrate, depressed uterine wet weight ( $T$ able 4). In addition, elevation of uterine wet weight normally observed in estradiol treated rats was not apparent in animals receiving estradiol in conjunction with the glyoxals (Table 5). These data suggest a glyoxal mediated blockade of at least one parameter of estrogen response.

Before any further study involving estradiol, glyoxals, and uterine histone acetylation could be attempted, it was necessary to delineate the action of estradiol on acetylation properties of the hormone stimulated uterus, so that we would then be able to evaluate glyoxal mediated alterations of this system more precisely.

An initial effect of estradiol treatment on the rat uterine acetylation system was the depression of histone acetylation in this organ (Figure 2). This action was very rapid and resulted in a depression in enzyme activity measurable as early as 10 minutes following hormone treatment. Our data a re not in agreement with Libby (1971), who reported a rapid stimulation of histone acetylation immediately following estradiol treatment, peaking at approximately 15 minutes and 
returning to control levels 20 minutes following estradiol treatment. However, our results do agree with Anderson and Gorski (1971), who demonstrated that estradiol caused an early decrease in histone acetylation followed by an increase, beginning at about 18 hours and elevating to 150 percent of control 24 hours after hormone treatment. Kaye and Sheratzky (1969) have previously shown a decrease in the activity of protein (histone) methylase obtained from the centrifuged $(105,000 \times \mathrm{g})$ supernatant fraction obtained from rat uterus of estradiol treated animals. The differences in dose schedule, observation times, and assay procedure may account for the lack of agreement of the results of these studies.

Phenylglyoxal, $250 \mathrm{mg} / \mathrm{kg}$, intrape ritoneally, decreased enzyme activity when administered one hour prior to estradiol treatment (Figure 2). The mean enzyme activity for phenylglyoxal pretreated groups receiving estradiol tended to be lower than the mean values of estradiol treated groups at 0,5 , and 10 minutes following hormone treatment. Although not statistically significant $(P>.05)$, the se values suggest that a longer pretreatment period might result in a greater difference between these groups.

Phenylglyoxal pretreatment, followed by estradiol, significantly lowered $(P<.05)$ histone acetylation activity as compared both to control groups and to estradiol treated groups, when measured 15 minutes following estradiol treatment. The apparent early inhibitory 
effect upon uterine histone acetylation by estradiol was unexpected in that stimulation of hormonally excitable systems generally results in an early augmentation of histone acetylation (Allfrey, 1966; Pogo et al. , 1966; Pogo and Allfrey, 1968).

Data presented in Figure 3 indicate that one of the initial effects mediated by estradiol is a virtually complete inhibition of uterine histone acetylation. The time course of the latter reversal of the initial inhibition and subsequent stimulation of histone acetylation to levels above control may be pertinent when estrogen mediated alterations in uterine RNA and protein content are considered. In the studies of Oliver and Kellis (1970), RNA (ug/mg dry weight) in the immature rat uterus remained relatively constant up to 10 hours after treatment with $5 \mu \mathrm{g}$ of estradiol. Elevation of uterine RNA levels reportedly occurred between 10 and 12 hours following estradiol, whereas uterine DNA (ug/mg dry weight) decreased during the same interval. Administration of estradiol to ovariectomized rats resulted in a measurable elevation in the RNA/DNA ratio, commencing approximately 8 hours and continuing up to 24 hours after hormone administration. Results of the present study suggest that the estradiol mediated elevation in uterine histone acetylation occurred at a time when uterine RNA levels were increasing through the action of this hormone. These findings are in accord with other workers who have observed an elevation in histone acetylation preceding or 
paralleling rises in RNA and protein in several unrelated systems (Allfrey et al., 1963; Pogo et al. , 1966; Pogo et al., 1969).

Measurement of uterine histone acetylation activity following phenylglyoxal treatment (Figure 3) demonstrated the ability of this drug to cause a rapid depression in uterine enzyme activity, with peak depression corresponding to approximately 60 percent inhibition 4 hours following phenylglyoxal administration. Enzyme activity remained depressed up to 24 hours. The effect of both estradiol and phenylglyoxal on uterine histone acetylation and alterations in uterine wet weight followed similar temporal patterns during the first 2 hours of drug activity (Figure 4).

The apparent decrease in uterine wet weight following phenylglyoxal treatment was not significant (Figure 4), although it is assumed from the results presented in Table 1 that more prolonged adminis tration of phenylglyoxal would most likely depress uterine wet weight. The rapid elevation in uterine wet weight following estradiol adminis tration to immature female rats is well characterized, and it is thought to be primarily a hypertrophic response. Water uptake in the ute rus of estradiol treated rats reaches a peak 4 to 6 hours after hormone treatment. The initial water inhibition was followed by a second similar response after 12 hours (Mueller, 1971). Uterine wet weight, measured 24 hours after hormone administration to ovariectomized rats, has been shown to increase approximately 190 percent above 
untreated controls (Hamilton et al., 1968). In our study, uterine wet weight alterations seen in 25-30 day old female rats following estradiol treatment were similar to those previously reported (Figure 4). The physiological effects characteristic of estradiol we re evident throughout the period uterine histone acetylation was monitored. It is difficult at this time to present a completely satisfactory explanation of the biological role this hormone plays in its initial action on histone acetylation in its target organ. Barker (1971) showed that the synthesis of arginine-rich histones in rat ute rus following estradiol treatment was elevated immediately. The rate of synthesis decreased toward control levels 6 hours after treatment and then became steadily elevated to a 22 -fold increase 48 hours following estradiol. Surprisingly, the amount of arginine-rich histone per ute rus decreased dramatically to 44 percent of control levels 1 hour following estradiol administration, remaining depressed until approximately 10 hours after estradiol when it returned to control levels; and then when measured 12 hours following hormone treatment, they became elevated to 138 percent of control values. Estradiol mediated alterations in uterine histone synthesis and content observed in these studies somewhat paralleled the pattern of alterations in histone acetylation reported in our work.

These results may offer an explanation of some of the alterations observed following estradiol administration. Barker (1971) suggests 
that hydrolysis of histone protein may account for its disappearance in the ute rus immediately following estradiol treatment. Paik and Lee $(1970 ; 1971)$ have reported an enzyme which specifically hydrolyzes histone protein. Earlier, Goodall (1965) reported an increase in uterine proteolytic activity following estradiol adminis tration. We suggest that, if such an enzyme exists in the uterus, the elevation of its activity by estradiol, eithe $r$ through activation mechanisms or through de novo synthesis, would account for the rapid depression in arginine-rich histone content in the estradiol treated ute rus. Control mechanisms involved in the depression of histone content by the hormone might also be responsible for a decrease in the activity of an enzyme involved in the control of histone modification. Any continuation of the normal cellular levels of uterine histone acetylation in the face of rapidly decreasing histone levels following estradiol would not be efficient, whereas a corresponding decrease in enzyme activity to parallel the depleted uterine histone content would be reasonable. As the highly elevated rate of histone synthesis negated the effect of elevated histone degradation, normal histone levels would be reestablished and a "feedback" type of control of hormonal stimulation would be accomplished. A return of uterine histone acetylation capacity following estradiol would be expected to follow the observed rise in histone content, since histone modification would again be required. 
Barker's observation that the levels of uterine arginine-rich histones were elevated to above control values 12 hours after estradiol coupled with our findings that such elevation precedes the reversal in the initial depression in histone acetylation, are consistent with this proposed model of estradiol mediated alterations in histone metabolism. We suggest that an alteration in histone metabolism other than by acetylation may be implicated in the initial derepression mechanisms thought to occur in the estradiol stimulated rat uterus. Our previous study established that estradiol elevates uterine histone acetylation when measured 24 hours following hormone treatment. Furthermore, phenylglyoxal depressed this parameter with peak depression in activity occurring 4 hours following drug . administration. By aligning these time intervals, it was possible to measure the effect of glyoxal treatment on the established elevation of uterine histone acetylation 24 hours after hormone treatment. Uterine wet weight was utilized as a secondary measurable parameter to monitor the net physiological action of estradiol and phenylglyoxal. The data obtained from this study suggest that 4 hour treatment with either methylglyoxal or phenylglyoxal is ineffective in itself in altering ute rine wet weight significantly (Tables 6, 7). Similarly, the elevations in uterine wet weight in estradiol treated animals receiving phenylglyoxal or methylglyoxal suggest that the glyoxals do not reverse the initial uterine hypertrophy following hormone treatment manifest 
at the time of glyoxal administration. These data are consistent with the view that early water imbibition of the uterus, which accounts for most of the elevated uterine wet weight following estradiol, is an extragenomic action of the hormone. Ui and Mueller (1963) have shown that water imbibition of the uterus following estradiol takes place even when uterine RNA synthesis has been blocked by actinomycin-D; their findings support the contention that the process of ute rine imbibition is not completely under genomic control. It is the refore conceivable that the depression of uterine histone acetylation activity by methylglyoxal and phenylglyoxal treatment or the apparent reversal of the estradiol mediated elevation in enzyme activity ( $\mathrm{T}$ ables 6, 7; Figures 5, 6) might not be expected to influence all measurable parameters in the uterus in a parallel manner.

An analysis of uterine tissue obtained from phenylglyoxal treated animals 4 hours after drug administration failed to show any alteration in the parameters monitored in this study ( $\mathrm{T}$ able 10$)$. Since uterine histone acetylation is depressed by this treatment, it is evident that the - depressed enzyme activity precedes any measurable alteration in nucleic acids and protein content, as reflected by the total DNA, RNA/DNA and protein/DNA ratios. Pogo et al. (1966) reported that RNA synthesis in equine polymorphonuclear leucocytes following treatment with phytohemaglutinin in vitro was diminished. Furthermore, preliminary experiments suggest that an inhibition of histone acetylation 
in this system may precede the observed decrease in RNA synthesis. Since we have measured levels rather than synthesis of uterine nucleic acids following 4 hours glyoxal treatment, it was not unexpected that little or no alte ration in nucleic acid content following short term glyoxal treatment was noted. However, by extending the period of glyoxal treatment from 4 to 48 hours, it was possible to demonstrate a more pronounced effect of phenylglyoxal on the uterus of estradiol treated animals. Although phenylglyoxal does not lower ute rine wet weight when given alone, the drug is capable of decreasing the magnitude of uterine weight gain seen after administration of the hormone (Table 11). This action is significant in that it demonstrates the ability of an endogenous metabolite to interfere with the physiological action of a steroid hormone. Alterations of nucleic acid and protein constituents of the estrogen stimulated uterus become apparent when measured in phenylglyoxal pretreated animals receiving the hormone (Table 12). Elevations in total uterine DNA and the protein/DNA ratio following estradiol are not attained in phenylglyoxal pretreated animals (Table 13). Phenylglyoxal apparently does not affect the estrogen mediated elevation of the DNA/RNA ratio. These data are in general agreement with other studies concerned with the action of the glyoxals in various biological systems. In studies using human kidney cells, Scaife (1969) found that kethoxal and methylglyoxal were potent inhibitors of protein synthesis in this system; DNA 
synthesis was partially blocked, whereas RNA synthesis was only slightly influenced. A similar patte rn of glyoxal mediated alterations in DNA, RNA and protein synthesis has been described by SzentGyorgyi (1967). Klamerth (1968) has also reported that the principal effect of glyoxal $(0.5 \mathrm{mM})$ on human cells grown in culture is a depression in both DNA and protein synthesis, leading him to believe that DNA replication rather than transcription is being blocked by the glyoxals.

In light of the results presented here and in related studies, the possible consequences of glyoxal mediated inhibition of the acetylation of histones involved in the control of DNA replication warrant consideration if a mechanism of action is to be determined for the known biological activity of the ketoaldehydes. If the ketoaldehydes are important agents in the regulation of histone acetylation, this suggests that they may be therapeutically useful in inducing a termination of cellular prolife ration. 


\section{SUMMARY AND CONCLUSIONS}

The ketoaldehydes, phenylglyoxal and methylglyoxal, inhibit the in vitro acetylation of histones by a cell-f ree soluble fraction of $r a t$ uterus. The degree of enzyme inhibition is dose related. As determined by the reported $I_{50}$ value for each drug, methylglyoxal and phenylglyoxal are equally effective in inhibiting histone acetylation.

In vitro inhibition of ute rine histone acetylation by phenylglyoxal is thought to be accomplished primarily by inhibition of the ute rine enzyme system. However, the formation of a glyoxal-histone complex which is a product less capable of undergoing acetylation is also suggested by our data. The importance of these actions in vivo cannot be assessed at this time.

Immature female rats treated for six days with glyoxal monohydrate gain less weight than vehicle treated controls, whereas Methyl-GAG had no effect on this parameter. The decrease in uterine wet weight following glyoxal treatment was not as evidence in MethylGAG treated rats. Estradiol mediated elevations in uterine/body ratios are blocked or reversed by prior treatment with Methyl-GAG and glyoxal monohydrate, respectively. Uterine/body weight ratios but not liver/body weight ratios were altered when measured in animals receiving the glyoxals and estradiol.

The hormonally stimulated immature rat uterus was developed as a model system in which to measure estradiol and ketoàldehyde 
induced alterations in uterine histone acetylation. Various parameters were monitored in order to delineate more clearly the actions of both the glyoxals and estradiol on the physiology and biochemistry of the system under study. The temporal relationships of the alterations induced by these agents may offer an alternate explanation for the biological action of both the hormone and the proposed inhibitor.

A rapid depression in uterine histone acetylation occurred following estradiol administration to immature rats. The initial hormonal action on uterine histone acetylation was reversed over the initial 24 hours, leading to an elevation above control levels. The depression in uterine histone acetylation occurred during the period in which hormonally induced elevations in uterine wet weight were observed. These findings suggest that an elevation in histone acetylation may not be an initial event in the general stimulation of the immature uterus by estradiol.

Four hour treatment with methylglyoxal and phenylglyoxal reversed the estradiol mediated elevation in uterine histone acetylation, without affecting uterine wet weight. The phenylglyoxal mediated inhibition of uterine histone acetylation preceded any alteration in ute rine wet weight, total DNA, RNA/DNA or protein/DNA ratio.

When the duration of phenylglyoxal treatment was extended to 48 hours in order to measure the effectiveness of the drug in altering 
the actions of estradiol on various parameters of the model system under study, depressions in uterine RNA/DNA and protein/DNA ratios occurred. Estradiol-mediated elevations in uterine wet weight, total DNA and the protein/DNA ratio were partially blocked by this treatment. The drug was ineffective in blocking the elevation in RNA/DNA ratio produced by estradiol. The alteration of normal physiological activity in the immature rat uterus by phenylglyoxal became most apparent when this action was monitored in a hormonally activated system.

Although no direct correlation between the initially depressed rate of histone acetylation preceding the decrease of uterine nucleic acid levels can be made, we suggest that blockade of the normal pattern of histone modification following hormone administration may lead to parallel depressions in levels of key intermediates necessary for the complete accomplishment of hormonal action. 


\section{REFERENCES}

Allfrey, V.G., Littau, V.C. and Mirsky, A.E.: On the role of histones in regulating ribonucleic acid synthesis in the cell nucleus. Proc. Nat. Acad. Sci., U.S.A. 49: 414-421, 1963.

Allfrey, V.G., Faulkner, R. and Mirsky, A.E.: Acetylation and methylation of histones and their possible role in the regulation of RNA synthesis. Proc. Nat. Acad. Sci., U.S.A. 51: 786-795, 1964.

Allfrey, V.G.: Control mechanisms in ribonučleic acid synthesis. Cancer Res. 26: 2026-2040, 1966.

Anderson, N. O. and Gorski, J.: Effect of estrogen on synthesis and acetylation of histones in rat uteri. Fed. Proc. 30: 361, 1971.

Avdalovic, N. and Kochakian, C. D.: Androgen regulation of RNA polyme rase activity in insolated mouse kidney nuclei. Biochem. Biophys. Acta. 182: 382-393, 1969.

Bach, F. and Hirschorn, K. : Gamma-globulin production by human lymphocytes in vitro. Exptl. Cell Res. 32: 592-595, 1963.

Barker, K. L.: Estrogen-induced synthesis of histones and a specific nonhistone protein in the uterus. Biochemistry 10: 284-291, 1971.

Bondy, S. C., Roberts, S. and Morelos, B.S.: Histone acetylating enzyme of brain. Biochem. J. 119: 665-672, 1970 .

Bradbury, E. M.: Conformation of nucleohistones and histones. Biochem. J. 114: 49-51, 1969.

Bresnick, E.: The effect of hormones on nucleic acid and protein synthesis. In Methods in Pharmacology, Vol. 1, ed. by A. Schwartz, pp. 455-477. Appleton-Century-Crofts, New York, 1971.

Butler, J.: Complexity and specificity of histones. In Histones, Their Role in the Transfer of Genetic Information. Ciba Foundation Study Group No. 24, ed. by A.V.S. deReuck and J. Knight, pp. 4-14. Little, B rown and Company, Boston, 1966.

Ceriotti, G.: Determination of nucleic acids in animal tissues. J. Biol. Chem. 214: 59-70, 1955. 
Combard, A. and Vendrely, R.: Analytical study of the degradation of nucleohistone during calf thymus chromatin autolysis. Biochem. J. 118: $875-879,1970$.

DeLange, R. and Smith, E.L.: Histones: structure and function. Ann. Rev. Biochem. 40:279-314, 1971 .

Edgar, J.A.: Is dehydroascorbic acid an inhibitor in the regulation of cell division in plants and animals? Experientia 25: 1214-1215, 1969.

Egyud, L.G. and Szent-Gyorgyi, A.: On the regulation of cell division. Proc. Nat. Acad. Sci., U.S.A. 56: 203-207, 1966.

Freedman, M.H., Grossberg, A.L. and Pressman, D. : Evidence for ammonium anil guanidinium groups in the combined sites of anti-p-azobenzenearsonate antibodies-separation of two different populations of antibody molecules. J. Biol. Chem. 243: 6186-6195, 1968.

Freireich, E.J., Frei, E. and Karon, M.: Methylglyoxal bis (guanylhydrazone): a new agent active against acute myelocytic leukemia. Proc. II CCNiSC Conference on Experimental Clinical Cancer Chemothe rapeutics. Cancer Chemotherap. Rep. 16: 183-186, 1962.

French, F.A. and Freelander, B. L. : Carcinostatic action of polycarbonyl compounds and their derivatives. I. 3-ethoxy-2-ketobutyraldehyde and related compounds. Cancer Res. 18: 172-175, 1958.

Georgiev, G.P.: Histones and the control of ge ne action. Ann. Rev. 3 : $155-179,1969$.

Goodall, F.R.: Degradative enzymes in the ute rine myometrium of rabbits uncler different hormonal conditions. Arch. Biochem. Biophys. $112: 403-410,1965$.

Gorski, J., Noteboom, W. D. and Nicolette, J.A.: Estrogen control of the synthesis of RNA and protein in the uterus. J. Cell Comp. Physiol. 66: $91-110,1965$.

Gregg, Ch. T.: Inhibition of mammalian cell division by glyoxals. Exptl. Cell Res. 50:65-72, 1968.

Hamilton, T.H.: Control by estrogen of genetic transcription and translation. Science 161: 649-660, 1968. 
Hamilton, T.H., Teng, C. and Means, A. R. : Early estrogen action: nuclear synthesis and accumulation of protein correlated with enhancement of two DNA-dependent RNA polymerase activities. Proc. Nat. Acad. Sci., U.S.A. 59: 1265-1272, 1968.

Henderson, E.S.: Treatment of acute leukemia. Seminars in Hematol. 6: No. 3, 271-319, 1969.

Hilton, J. and Stocken, L. A. : The role of thiol groups in the modification of the template activity of histone-deoxy ribonucleic acid complexes. Biochem. J. 100: 21-22, 1966.

Inoue, A. and Fujimoto, D.: Enzymatic deacetylation of histone. Biochem. Biophys. Res. Comm. 39: 146-150, 1969.

Jensen, E.V., Suzuki, T., Kawashima, T., Stumpf, W. E., Jungblut, P.W. and DeSombre, E.R.: A two-step mechanism for the interaction of estradiol with rat uterus. Proc. Nat. Acad. Sci., U.S.A. 59: $632-638,1968$.

Kaye, A. M. and Sheratzky, D.: Methylation of protein (histone) in vitro: enzymic activity from the soluble fraction of rat organs. Biochem. Biophys. Acta. 190: 527-538, 1969.

Kenney, F.T., Reel, J.R., Hager, C.B. and Wittliff, J. L: Hormonal induction and repression. In Regulatory Mechanisms for Protein Synthesis in Mammalian Cells, ed. by A. San Pietro, M. Lamborg and F. Kenney, pp. 119-142. Academic Press, New York, 1968.

Klamerth, O. L. : Influence of glyoxal on cell function. Biochem. Biophys. Acta. 155: 271-279, 1968.

Langan, T.A.: Acttion of adenosine 3,-5'-monophosphate-dependent histone kinase in vivo. J. Biol. Chem. 244: 5763-5765, 1969.

Lewin, S.: The mechanism and energetics of histone associations with deoxyribonucleic acid. Biochem. J. 119: 62-63, 1970.

Libby, P. R.: Histone acetylation by cell-free preparations from rat uterus: in vitro stimulation by estradiol $-17-\beta$. Biochem. Biophys. Res. Comm. 31: 59-65, 1968.

Libby, P. R.: Estrogen stimulation of histone acetylation in uterus. Fed. Proc. 30: 361, 1971. 
Lowry, O.H., Rosebrough, N. T., Farr, A. L. and Randall, R. J.: Protein measurement with the folin phenol reagent. J. Biol. Chem. 193: $265-275,1951$.

Monder, C. and Walker, M. C.: Interactions between corticosteroids and histones. Biochemistry 9: 2489-2497, 1970.

Mueller, G.C.: Estrogen action: a study of the influence of ste roid hormones on genetic expression. In The Biochemistry of Steroid Hormone Action. Biochemical Society Symposium No. 32, pp. 1-29, Academic Press, New York, 1971.

Oliver, J.M. and Kellie, A.E.: The effects of oestradiol on the acid-soluble nucleotides of rat uterus. Biochem. J. 119: 187-191, 1970.

Ord, M.G. and Stocken, L.A.: Further studies on phosphorylation and the thiol/disulfide ratio of histones in growth and development.

Biochem. J. 112: 81-89, 1969.

Paik, W. K. and Kim, S.: Enzymatic methylation of histones. Arch. Biochem. Biophys. 134: 632-637, 1969.

Paik, W. C. and Lee, H.W.: Enzymatic hydrolysis of histones in rat kidney microsomes. Biochem. Biophys. Res. Comm. 38: 333-340, 1970.

Paik, W.K., Pearson, D., Lee, H.W. and Kim, S. : Nonenzymatic acetylation of histones with acetyl-Coa. Biochim. Biophys. Acta. 213: $513-522,1970$.

Paik, W.K. and Kim, S.: Protein methylation. Science 174: 114-118, 1971.

Paik, W. K. and Lee, H. W. : Histone hydrolase in tadpole liver. Experientia 27: $630-632,1971$.

Pogo, B.G.T., Allfrey, V.G. and Mirsky, A. E.: RNA synthesis and histone acetylation during the course of gene activation in lymphocytes. Proc. Nat. Acad. Sci., U.S.A. 55: 805-812, 1966.

Pogo, B.T.T., Pogo, A.O., Allfrey, V.G. and Mirsky, A.E.: Changing patterns of histone acetylation and RNA synthesis in regeneration of the liver. Proc. Nat. Acad. Sci., U.S.A. 59: 1337-1344, 1968.

Pogo, B.G.T., Pogo, A.O. and Allfrey, V.G.: Histone acetylation and RNA synthesis in rat liver regeneration. Genetics Suppl. 61: 373-379, 1969. 
Procaccini, R. L., DeFanti, D.R. and DeFeo, J.J.: Inhibition of in vitro histone acetylation in a cell-free rat uterine system by methylglyoxal and phenylglyoxal. Biochem. Biophys. Res. Comm. 43: $484-487,1971$.

Richards, B.M. and Pardon, J.F.: The molecular structure of nucleohistone (DNH). Exptl. Cell Res. 62: 184-196, 1970.

Robinson, J.R.: Some effects of glucose and calcium upon the metabolis $m$ of kidney slices from adult and newborn rats. Biochem. J. 45: $68-76,1949$.

Rubin, A. D. and Cooper, H. L.: Evolving patterns of RNA metabolism during transition from resting state to active growth in lymphocytes stimulated by phytohemagglutinin. Proc. Nat. Acad. Sci., U.S.A. 54: $469-475,1965$.

Scaife, J.F.: Mitotic inhibition induced in human kidney cells by methylglyoxal and kethoxal. Experientia 25:178-179, 1969.

Schneider, W.C.: Phosphorous compounds in animal tissues. I. Extraction and estimation of deoxypentose nucleic acid and of pentose nucieic acid. J. Biol. Chem. 161:293-303, 1945.

Sluyser, M.: Binding of hydrocortisone to rat liver histones. J. Mol. Biol. 19: $591-595,1966$.

Sluyser, M.: Interactions of ste roid hormones with histones. Biochem. J. 118: 1 p., 1970 .

Stedman, E. and Stedman, E.: Cell specificity of histones. Natire 166: $780-781,1950$.

Sunaga, K. and Koide, S.S.: Interaction of calf thymus histones and DNA with steroids. Steroids 9:451-456, 1967.

Szent-Gyorgyi, A. , Egyud, L.G. and McLaughlin, J.A. : Ketoaldehydes and ceil division. Science 155: 539-541, 1967.

Szent-Gyorgyi, A.: Bioelectronics, A Study in Cellular Regulation, Defense, and Cancer. Academic Press, New York, 1968.

Takahashi, K.: The reaction of phenylglyoxal with arginine residues in proteins. J. Biol. Chem. 243: 6171-6179, 1968. 
Teng, C. and Hamilton, T.H.: Role of chromatin in estrogen action in the uterus, II. Hormone-induced synthesis of nonhistone acidic proteins which restore histone-inhibited DNA-dependent RNA synthesis. Proc. Nat. Acad. Sci., U.S.A. 63: 465-472, 1969.

Truong, H. and Baulieu, E.: Interaction of uterus cytosol receptor with estradiol equilibrium and kinetic studies. Biochem. Biophys. Acta. 237: 167-172, 1971 .

Tsanev, R. and Sendov, B. : Possible molecular mechanism for cell differentiation in multicellular organisms. J. Theoret. Biol. 30: $337-395,1971$.

Vi, H. and Mueller, G. C. : The role of RNA synthesis in early estrogen action. Proc. Nat. Acad. Sci., U.S.A. 50: 256-260, 1963.

Vince, R. and Wadd, W.B.: Glyoxalase inhibitors as potential anticancer agents. Biochem. Biophys. Res. Comm. 35: 593-597, 1969.

Wilhelm, J.A. and McCarthy, K.S. : Partial characterization of the histones and histone acetylation in cell cultures. Cancer Res. 30: 409-418, 1970. 


\section{VITA}

Robert Louis Procaccini was born on February 9, 1942 to Mr. \& Mrs. Domenic Procaccini in Providence, Rhode Island. Mr. Procaccini completed his elementary education requirements in Providence, Rhode Island. In 1959, Mr. Procaccini graduated from LaSalle Academy in Providence and entered the University of Rhode Island where he received the Bachelor of Science Degree in Pharmacy in June, 1964. Requirements for license as a Registered Professional Pharmacist of the State of Rhode Island were completed in July, 1964. Mr. Procaccini received the Master of Science Degree in Pharmacology in June, 1969, and the Doctor of Philosophy Degree in Pharmaceutical Science in June, 1972. He is a member of Theta Delta Chi Fraternity and the Rho Chi and Phi Sigma Societies. Mr. Procaccini is married to the former Ruth Ann Brooks of Tiverton, Rhode Island. 
APPENDIX 
The data presented in this appendix is complementary in nature and serves to more clearly characterize the uterine histone acetylation system employed in this study.

Significant histone acetylation activity was observed in the mitochondrial, microsomal and supernatant $(100,000 \times \mathrm{g})$-fraction of $\mathrm{rat}$ uterus obtained from immature (25 day old) rats. Specific activities of $16,255,31,219$ and $157,563 \mathrm{DPM} / \mathrm{mg}$ protein were observed for these fractions, respectively (Appendix A). These data, expréssed as percent total activity versus percent total protein is represented in Appendix B. Enzyme activity was highest in the soluble (supernatant) rat uterus fraction.

The effect of temperature on in vitro histone acetylation is represented in Appendix C. Enzyme activity remains constant from $30^{\circ} \mathrm{C}$ to $38^{\circ} \mathrm{C}$ followed by an abrupt elevation at $40^{\circ} \mathrm{C}$ assay temperature. Enzyme activity declined sharply as the temperature exceeded $40^{\circ} \mathrm{C}$ and approached $60^{\circ} \mathrm{C}$. The $Q_{10}\left(37-45^{\circ} \mathrm{C}\right)$ value of the acetylating enzyme system is 1.77 .

The elevation in histone acetylation activity at $40^{\circ} \mathrm{C}$ was used as a basis for studying reversibility of this activity. Enzyme preparations preincubated at an elevated temperature $\left(40^{\circ} \mathrm{C}\right)$ retained their elevated acetylation activity when assayed at the standard incubation temperature of $37^{\circ} \mathrm{C}$ (Appendix D). Enzyme preparations containing equal 
aliquots of enzyme preincubated at $37^{\circ} \mathrm{C}$ and at $40^{\circ} \mathrm{C}$ demonstrated activity slightly less than additive 
APPENDIX A

Subcellular Localization and Specific Activity of Histone Acetylation In Immature Rat Uterus 


\begin{tabular}{lcc}
\hline Fraction & $\begin{array}{c}\text { Specific Activity } \\
\text { (dpm/mg protein) }\end{array}$ & $\begin{array}{c}\text { Percent of } \\
\text { Total Activity }\end{array}$ \\
\hline Nuclei & 4,610 & 2.2 \\
Mitochondria & 16,255 & 7.8 \\
Microsomes & 31,219 & 14.8 \\
$\begin{array}{l}\text { Supernatant } \\
\text { (105,000 } \mathrm{x} \text { g) }\end{array}$ & 157,563 & 75.2 \\
\hline
\end{tabular}

${ }^{2}$ A weighed sample of rat uterus was homogenized in $0.25 \mathrm{M}$ sucrose and centrifuged at $780 \times \mathrm{g}$ for 15 minutes, and $105,000 \times \mathrm{g}$ for 60 minutes to obtain nuclear, mitochondrial, and microsomal pellets, respectively. Pellets were washed in $0.25 \mathrm{M}$ sucrose and resuspended to volume in Robinson's media (Robinson, 1949). A $0.05 \mathrm{ml}$ aliquot of each fraction was used as enzyme source for assay of histone acetylation. 


\section{APPENDIX B}

Subcellular Localization and Specific Activity of Histone Acetylation In Immature Rat Uterus 


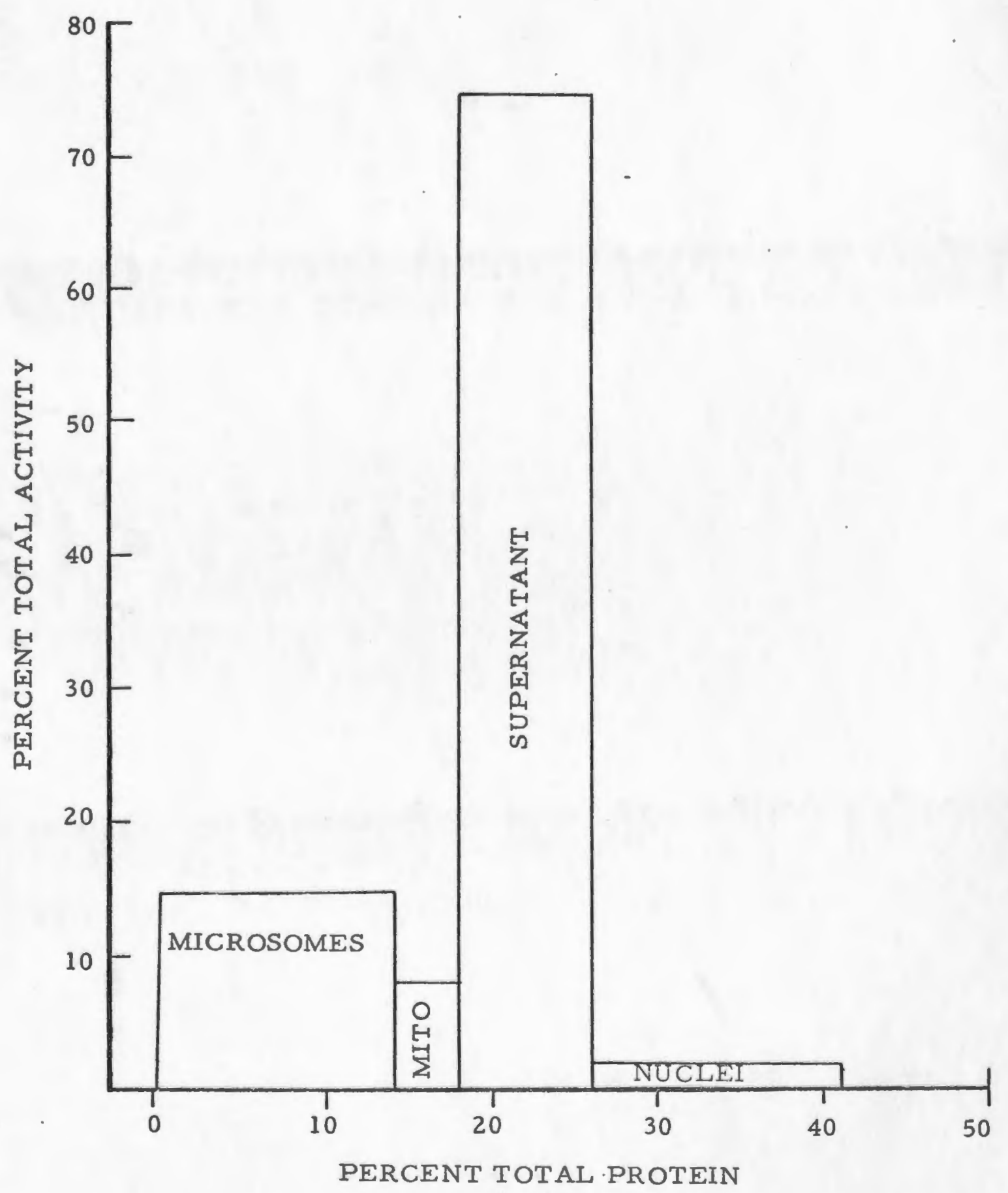


APPENDIX C

Effect of Temperature on in vitro Histone Acetylation 


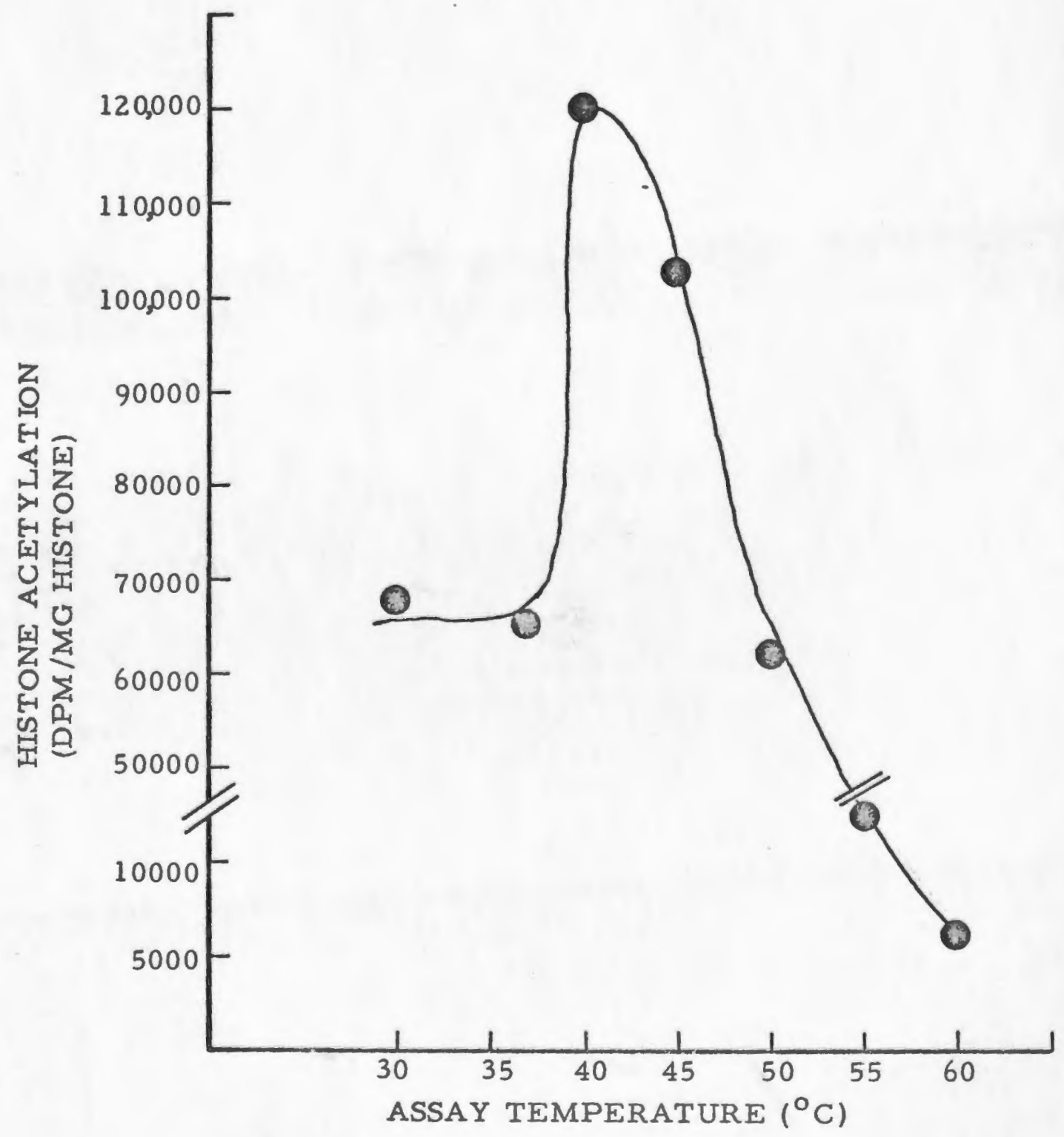




\section{APPENDIX D}

In vitro Thermal Activation of Histone Acetylation Properties of Rat Uterine Supernatant Fraction 


\begin{tabular}{|c|c|c|c|}
\hline Series & $\begin{array}{l}\text { Preincubation } \\
\text { Temperature }\end{array}$ & $\begin{array}{c}\text { Assay } \\
\text { Temperature }\end{array}$ & $\begin{array}{c}\text { Histone } \\
\text { Acetylation } \\
\text { (dpm/mg Histone) } \\
\text { Mean IS. E. * }\end{array}$ \\
\hline $\mathrm{I}^{2}$ & $37^{\circ} \mathrm{C}$ & $37^{\circ} \mathrm{C}$ & $13,793 \pm 1885$ \\
\hline$I^{b}$ & $40^{\circ} \mathrm{C}$ & $37^{\circ} \mathrm{C}$ & $26,313 \pm 2680$ \\
\hline $\mathrm{III}^{\mathrm{C}}$ & $\begin{array}{l}37^{\circ} \mathrm{C} \\
40^{\circ} \mathrm{C}\end{array}$ & $37^{\circ} \mathrm{C}$ & $18,220 \pm 1115$ \\
\hline
\end{tabular}

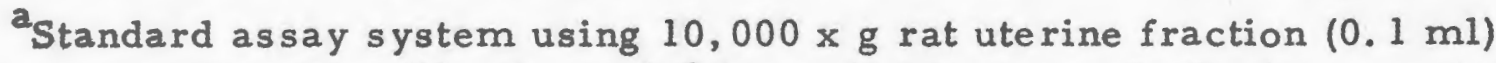
preincubated for $20 \mathrm{~min}$ at $37^{\circ} \mathrm{C}$, cooled on ice and added to complete as say system for incubation at $37^{\circ} \mathrm{C}$ for an additional $15 \mathrm{~min}$. Prior to incubation, uterine fraction was diluted $(1: 1)$ with Robinson's media.

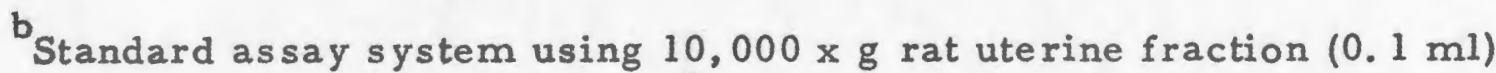
preincubated for $20 \mathrm{~min}$ at $40^{\circ} \mathrm{C}$, cooled on ice and added to complete assay system for incubation at $37^{\circ} \mathrm{C}$ for an additional $15 \mathrm{~min}$.

Uterine fraction was diluted $(1: 1)$ as above.

${ }^{\mathrm{c}}$ Standard assay system using combined supernatant fraction prepared by mixing $0.1 \mathrm{ml}$ aliquots of undiluted Series I and II treated supernatant with $0.2 \mathrm{ml}$ Robinson's media. At time of assay, $0.1 \mathrm{ml}$ of final mixture was added to complete assay system for incubation at $37^{\circ} \mathrm{C}$ for $15 \mathrm{~min}$.

* Mean IS.E. (for three determinations). 